\title{
Resource Augmentation for Meeting the Millennium Development Goals in the Asia Pacific Region
}

\author{
Raghbendra Jha \\ Australia South Asia Research Centre \\ Research School of Pacific \& Asian Studies \\ Australian National University \\ and \\ T. Palanivel \\ UNDP
}

March 2007

JEL Classification: E01, E61, F42, F29

Keywords: Millennium Development Goals, Asia Pacific Countries, Resource Augmentation

All correspondence to:

Raghbendra Jha,

Professor and Executive Director,

Australia South Asia Research Centre,

Research School of Pacific \& Asian Studies,

Australian National University,

Canberra, ACT 0200, Australia

Ph: +61261252683

$+61261254482$

Fax:+61 261250443 


\begin{abstract}
This paper examines whether the resource positions of the developing counties in the Asia Pacific region and the support they are receiving from donor countries are adequate to ensure that the MDG will be attained by 2015. It begins by examining the extant record of economic growth and emphasises the need for higher economic growth in order to accelerate the pace of poverty reduction. It argues that neither the level of economic growth nor its current structure can ensure that MDG1 is attained by 2015.
\end{abstract}

The paper argues that domestic savings and investment rates in most large developing countries in the Asia Pacific region are not high enough for growth rates to rise high enough to ensure that MDG1 (halving poverty measured at \$1 PPP per capita over the period 1990-2015) is attained. Further, the ICOR in most of these countries has been stagnant or rising in many of these countries so that it would be unrealistic to expect sharp enough rises in the productivity of capital to ensure that existing investment rates can ensure that MDG1 is attained by 2015.

The paper then examines some of the reasons for this lacklustre performance. Tax revenues have been stagnant and public expenditures on education and health have been low whereas many developing countries in the Asia Pacific region bear substantial burdens of debt servicing. Many of these countries also face considerable capital flight, exacerbating already tentative external situations. Furthermore whereas the current outlook for FDI looks promising for some Asian countries, international aid has been stagnant and in, many cases, net financial flows into developing countries has been negative.

The paper then considers avenues for increasing the resource base for these counties. It considers a variety of measures including tax reform and expenditure switching policies. It advances policies to reduce capital flight and argues that international debt reduction should accompany any policy to increase international aid to the developing countries of the Asia Pacific region. It lists a number of additional sources of multilateral aid that could replenish developing country resources but argues that measures to increase the absorptive capacity of developing countries as well as reduction in the volatility of aid must accompany to increase international aid. Further, increases in international aid should ensure that the real exchange rates of the recipient countries should not rise. If the real exchange rates were to rise, some of these countries could be exposed to Dutch disease type of phenomena. 


\title{
Resource Augmentation for Meeting the Millennium Development Goals in the Asia Pacific Region*
}

\author{
Raghbendra Jha and T. Palanivel
}

\section{Introduction}

Attaining the Millennium Development Goals (MDG) has now become the driving impetus behind development policy. Now that less than ten years remain for the attainment of the MDG, working towards their attainment has taken on a certain urgency. The present paper is an attempt to briefly examine the challenges that remain and inquire whether the resource positions of the developing counties in the Asia Pacific region and the support they are receiving from donor countries are adequate to ensure that the MDG will be attained by 2015 .

This paper will examine prospects for MDG1 (reducing the Head Count Ratio at $\$ 1$ per capita PPP by half between 1990 and 2015) only and thus implicitly assume that movement towards other millennium goals will be made concurrently. Achieving this MDG is linked to faster growth and structural transformation, as it requires that the per capita consumption of over $40 \%$ of the population of the Asia and Pacific region should rise to a minimum of \$1 PPP per person per day. To achieve that level of consumption, it is reckoned that Asian developing and low-income countries must, on the average, grow at $7 \%$ per annum for the next decade or so. This high growth rate requires a much faster rate of investment than countries in the region usually experience. Hence either the investment/GDP ratios in these countries would have to rise sharply or there should be sharp drops in their incremental capital/output ratios (ICOR). ${ }^{1}$ In case domestic resources are deemed to be inadequate one would have to inquire into the prospects for garnering additional resources from external sources, in particular, foreign aid.

This paper inquires into such prospects and is organised as follows. In Section II we examine recent trends in poverty in the Asia Pacific region and examine prospects for higher economic growth. Section III examines the prospects for higher economic growth in the short run. Section IV considers some of the reasons why there are inadequate resources for development in the developing countries of the Asia Pacific region. Section V considers strategies for enhancing resources for development in the short run. Section VI focuses on the means to raise the inflow of international aid to these countries and preconditions for their successful utilization. Section VII concludes.

\footnotetext{
* All opinions expressed in this document are the sole responsibility of the authors and do not necessarily represent the views of the organisations for which they work.

${ }^{1}$ Some authors have estimated that the average investment/GDP ratio across the region would have to rise to 25 to $30 \%$ or the ICOR would have to fall to 3.5 .
} 


\section{Trends in Poverty in the Asia Pacific region}

The Millennium Development Goals encompass eight objectives. Many of these are, however, are linked to MDG1 and we use that as an indicators of the progress that is needed by 2015. Table 1 displays data on poverty trends in several Asia-Pacific countries and some regions. It also shows, wherever possible, targets implied by MDG1.

Table 1: Poverty Head Count Ratio \$1 Per Day (PPP) (\% of Population)

\begin{tabular}{|c|c|c|c|c|c|c|}
\hline Countries/Regions & $\begin{array}{l}\text { Average } \\
1981-85\end{array}$ & $\begin{array}{l}\text { Average } \\
1986-90\end{array}$ & $\begin{array}{l}\text { Average } \\
1991-95\end{array}$ & $\begin{array}{l}\text { Average } \\
1996-00\end{array}$ & $\begin{array}{l}\text { Average } \\
2001-03\end{array}$ & $\begin{array}{c}\text { Required } \\
\text { HCR in } 2015 \\
\text { to reach } \\
\text { MDG1 }\end{array}$ \\
\hline Bangladesha & 24.06 & 33.75 & 32.24 & 31.37 & & 16.87 \\
\hline Cambodia & & & & 34.08 & & \\
\hline China & & 30.75 & 28.40 & 17.60 & 16.60 & 16.50 \\
\hline \multicolumn{7}{|l|}{ Fiji } \\
\hline Indiab & & 46.31 & 42.31 & 35.30 & & 18.40 \\
\hline Indonesiac & & 28.15 & 17.39 & 15.55 & 7.51 & 15.40 \\
\hline Iran, Islamic Rep. & & 2.00 & 2.00 & 2.00 & & \\
\hline Korea, Rep. & & & & 2.00 & & \\
\hline Lao PDR & & & 7.75 & 26.33 & & \\
\hline Malaysia & 2.00 & 2.00 & 2.00 & 2.00 & & \\
\hline Nepal & 39.72 & & 39.13 & & & \\
\hline Pakistan & & 48.70 & 33.90 & 10.09 & & 23.88 \\
\hline Philippines ${ }^{d}$ & 22.76 & 18.20 & 19.07 & 14.94 & & 9.10 \\
\hline Sri Lanka & 9.39 & 3.82 & 6.56 & 7.60 & & 1.910 \\
\hline Thailande & 21.64 & 17.85 & 6.02 & 2.06 & & 8.92 \\
\hline Vietnam & & & 14.63 & 3.80 & 2.00 & \\
\hline East Asia \& Pacific & 48.30 & 28.80 & 24.90 & 16.15 & 14.90 & 14.80 \\
\hline South Asia & 49.15 & 43.15 & 40.10 & 34.40 & 31.30 & 20.60 \\
\hline Latin America \& Caribbean & 10.75 & 11.10 & 11.30 & 10.60 & 9.50 & 5.60 \\
\hline Middle East \& North Africa & 4.45 & 2.75 & 1.60 & 2.30 & 2.40 & \\
\hline Sub-Saharan Africa & 43.95 & 45.70 & 44.10 & 45.65 & 46.40 & \\
\hline Europe \& Central Asia & 0.60 & 0.45 & 3.70 & 5.30 & 3.60 & \\
\hline
\end{tabular}

a: Some data points are missing. The 2015 MDG1 target is computed as half of that in 1988 .

b: 2015 figure based on poverty computed using national poverty line for 1990-91.

c: several data points missing. 2015 estimate based on 1987 figure.

d: several data missing. 2015 estimate based on 1988 figure.

e: several data points missing. 2015 estimate based on 1988 figure

Source: Computed from WDI (2005)

This table reveals that only China and Thailand and, to a certain extent, Philippines are on track to meet MDG1. For another major country, India, comparable data since 2001 are not available and there was a major change in the methodology of the household surveys on which poverty computations are based in 1999-00. However, there is widespread acceptance that the rate of poverty decline during the 1990s has been slower than that during the 1980s and inequality - both personal as well as spatial - has increased (Jha 2004a). South Asia's poverty remains stubbornly high. The HCR for this region would have to fall by 10.7 points in the 12 year period 2003-2015 compared to the 10 point decline in the 13 years prior to it. This requires substantial acceleration in poverty reduction. 


\section{Prospects for higher growth}

In the extant literature higher economic growth has almost always been linked to reductions in poverty (Winters et al. 2002). Economic growth affects the poor both directly and indirectly. The direct effect channelled through personal income and social provisioning. Economic growth increases the personal income of the poor, as it increases the demand for poor people's assets (mainly labour) as well as for poor people's output. However, the extent to which growth translates into higher incomes of the poor can and does vary from country to country and time to time. This depends on the pattern and sources of growth as well as the manner in which its benefits are distributed.

Empirical evidence collated by a number of authors has shown that in an overwhelming majority of cases, the incomes of the poorest 20 percent of the population rise proportionately with average incomes. In some rare cases the incomes of the lowest income quintile of the population rise less than proportionately with average income (anti-poor growth) but there are many more cases of the incomes of the lowest quintile rising at a rate higher than average income (pro poor growth).

Similarly, Pasha and Palanivel (2004), by using poverty data drawn from national poverty line and other related variables, have demonstrated that key macroeconomic determinants of the variations in poverty incidence in the Asia are employment growth and agricultural growth. They have also showed that inflation, at least up to a certain rate, does not seem to matter in negatively impacting on poverty, while the role of exports is essentially indirect through the contribution to the overall rate of economic growth. Hence, one way of ensuring that the Asia Pacific countries reach MDG1 by 2015 is to ensure higher economic growth in this region.

It is clear that recent empirical studies strongly support the primacy of the role of economic growth in poverty reduction. Some recent studies also attempted to quantify the responsiveness of poverty to income growth by estimating the "growth elasticity" of poverty. These studies found that when alternative poverty lines were used to measure the incidence of poverty, the estimated growth elasticity was higher for lower poverty lines. The implication is that the incidence of extreme poverty was even more responsive to growth in average living standards than the incidence of moderate poverty.

We now inquire into the prospects for higher economic growth in the short-run and then comment on the resource positions in the Asia-Pacific countries. We examine the magnitudes of savings and investment and trends in public sector revenues, particularly in taxation. We find that investment rates and public sector revenues in the region are inadequate and not rising fast enough and, therefore, discuss some of the reasons underpinning this slackness. In particular, the paper focuses on inefficient taxation, capital flight and the presence of shadow economies and substantial corruption in these countries. Finally, the paper discusses prospects for augmenting resources for growth through external sources - foreign direct investment (FDI) and international aid.

\section{Trends in Economic Growth and Poverty Reduction in Asia and the Pacific}

According to the ADB Asian Development Outlook 2006, economic growth in developing Asia and the Pacific was estimated at $7.4 \%$, well above the average rate of 
growth in the region since 2000. If purchasing power parity weights, rather than weights based on market exchange rates, are used to aggregate over countries, regional growth in 2005 is estimated to have been even faster, at $8.0 \%$. With the release of revised gross domestic product estimates for 2004 in a number of countries, growth in 2004 has now been raised to $7.8 \%$ from $7.4 \%$. On the basis of a broadly favorable outlook for the international economy, the continuing trend toward improved economic management and performance, and apparent resilience to high oil prices, the ADO 2006 project that regional growth of $7.2 \%$ in 2006 and $7.0 \%$ in 2007.

Asia's surging economic growth has helped to reduce levels of poverty in the region, however, even if these growth rates were to be sustained, the per capita GDP growth magnitudes are simply incapable of achieving the MDG target of halving acute poverty by 2015 . This is shown in Table 2 .

Table 2: Trends in Per-Capita GDP Growth Rates: 1981-2004 (\% Per Annum)

\begin{tabular}{lccccc}
\hline Countries/Regions & $1981-1985$ & $1986-1990$ & $1991-1995$ & $1996-2000$ & $2001-2004$ \\
\hline Bangladesh & 1.1 & 1.1 & 2.5 & 3.3 & 3.3 \\
Bhutan & 4.7 & 5.9 & 2.7 & 3.7 & 3.5 \\
Cambodia & & & 4.6 & 4.1 & 3.7 \\
China & 9.2 & 6.2 & 10.6 & 7.2 & 7.9 \\
Fiji & -1.8 & 1.2 & 1.8 & 0.9 & 2.3 \\
India & 3.1 & 4.0 & 3.2 & 3.9 & 4.5 \\
Indonesia & 3.6 & 5.2 & 6.1 & -0.3 & 3.1 \\
Iran, Islamic Rep. & 1.5 & -2.3 & 2.8 & 1.9 & 4.6 \\
Korea, Rep. & 6.3 & 8.5 & 6.7 & 3.6 & 4.0 \\
Lao PDR & $1.9^{\star \star}$ & 1.7 & 3.7 & 3.6 & 3.3 \\
Malaysia & 2.4 & 3.7 & 6.7 & 2.4 & 2.1 \\
Maldives & & & & 5.7 & 4.2 \\
Mongolia & 3.6 & 0.6 & -9.5 & 1.7 & 4.0 \\
Myanmar & 2.8 & -3.6 & 4.1 & 6.9 & $8.2^{\star}$ \\
Nepal & 2.7 & 2.1 & 2.7 & 2.3 & 0.6 \\
Pakistan & 3.9 & 3.0 & 2.0 & 0.8 & 1.6 \\
Papua New Guinea & -1.2 & -1.2 & 6.1 & -1.2 & -1.7 \\
Philippines & -3.5 & 2.2 & -0.0 & 1.6 & 2.1 \\
Samoa & -1.1 & 0.4 & 0.5 & 3.0 & 1.3 \\
Sri Lanka & 3.7 & 2.4 & 4.1 & 3.6 & 2.2 \\
Thailand & 3.5 & 8.5 & 7.4 & -0.0 & 4.4 \\
Vietnam & $1.7^{\star *}$ & 2.3 & 6.1 & 5.4 & 5.9 \\
\hline East Asia \& Pacific & 5.7 & 5.7 & 8.5 & 4.9 & 6.5 \\
South Asia & 3.1 & 3.5 & 3.0 & 3.4 & 4.0 \\
Latin America \& Caribbean & -1.6 & 0.0 & 1.8 & 1.6 & 0.5 \\
Middle East \& North Africa & -2.0 & -0.6 & 1.0 & 1.4 & 1.7 \\
Sub-Saharan Africa & -1.8 & -0.4 & -1.4 & 0.8 & 1.5 \\
Europe \& Central Asia & & & -4.8 & 2.7 & 4.3 \\
Low income & 1.3 & 2.4 & 1.4 & 2.9 & 3.3 \\
Middle income & 0.4 & 1.2 & 1.6 & 2.8 & 2.6 \\
High income & 1.9 & 3.0 & 1.3 & 2.4 & 0.9 \\
\hline
\end{tabular}

Source: World Bank, WDI CD-ROM, 2003, and ADB key Indicators 2003

Note: * : Value of 2001, ** : Value of 1985 
It is instructive to juxtapose evidence on the head count ratio of poverty at \$1 PPP per person against that on growth of real GDP per capita. This is done in Table 3.

Table 3: Poverty Trends Vs. Per Capita Growth

\begin{tabular}{|c|c|c|c|c|c|}
\hline Countries/Regions & $\begin{array}{c}\text { HCR (per } \\
\text { capita growth) } \\
\text { Average } \\
1981-85\end{array}$ & $\begin{array}{c}\text { HCR (per } \\
\text { capita growth) } \\
\text { Average } \\
1986-90\end{array}$ & $\begin{array}{c}\text { HCR (per } \\
\text { capita growth) } \\
\text { Average } \\
1991-95\end{array}$ & $\begin{array}{c}\text { HCR (per } \\
\text { capita growth) } \\
\text { Average } \\
1996-00\end{array}$ & $\begin{array}{c}\text { HCR (per } \\
\text { capita growth) } \\
\text { Average } \\
2001-03\end{array}$ \\
\hline Bangladesh & $\begin{array}{c}24.06 \\
(1.1)\end{array}$ & $\begin{array}{c}33.75 \\
(1.1)\end{array}$ & $\begin{array}{c}32.24 \\
(2.5)\end{array}$ & $\begin{array}{c}31.37 \\
(3.3)\end{array}$ & (3.3) \\
\hline Cambodia & & & & $\begin{array}{c}34.08 \\
(4.1)\end{array}$ & \\
\hline China & & $\begin{array}{c}30.75 \\
(6.2)\end{array}$ & $\begin{array}{r}28.40 \\
(10.6)\end{array}$ & $\begin{array}{c}17.60 \\
(7.2)\end{array}$ & $\begin{array}{c}16.60 \\
(7.9)\end{array}$ \\
\hline India & & $\begin{array}{c}46.31 \\
(4.0)\end{array}$ & $\begin{array}{c}42.31 \\
(3.2)\end{array}$ & $\begin{array}{c}35.30 \\
(3.9)\end{array}$ & \\
\hline Indonesia & & $\begin{array}{c}28.15 \\
(5.2)\end{array}$ & $\begin{array}{c}17.39 \\
(6.1)\end{array}$ & $\begin{array}{l}15.55 \\
(-0.3)\end{array}$ & $\begin{array}{c}7.51 \\
(3.1)\end{array}$ \\
\hline Iran, Islamic Rep. & & $\begin{array}{r}2.00 \\
(-2.3)\end{array}$ & $\begin{array}{c}2.00 \\
(2.8)\end{array}$ & $\begin{array}{c}2.00 \\
(1.9)\end{array}$ & \\
\hline Korea, Rep. & & & & $\begin{array}{l}2.00 \\
(3.6)\end{array}$ & \\
\hline Lao PDR & & & $\begin{array}{c}7.75 \\
(3.7)\end{array}$ & $\begin{array}{c}26.33 \\
(3.6)\end{array}$ & \\
\hline Malaysia & $\begin{array}{c}2.00 \\
(2.4)\end{array}$ & $\begin{array}{c}2.00 \\
(3.7)\end{array}$ & $\begin{array}{l}2.00 \\
(6.7)\end{array}$ & $\begin{array}{c}2.00 \\
(2.4)\end{array}$ & \\
\hline Nepal & $\begin{array}{c}39.72 \\
(2.7)\end{array}$ & & $\begin{array}{c}39.13 \\
(2.7)\end{array}$ & & \\
\hline Pakistan & & $\begin{array}{c}48.70 \\
(3.0)\end{array}$ & $\begin{array}{c}33.90 \\
(2.0)\end{array}$ & $\begin{array}{c}10.09 \\
(0.8)\end{array}$ & \\
\hline Philippines & $\begin{array}{l}22.76 \\
(-3.5)\end{array}$ & $\begin{array}{c}18.20 \\
(2.2)\end{array}$ & $\begin{array}{l}19.07 \\
(0)\end{array}$ & $\begin{array}{c}14.94 \\
(1.6)\end{array}$ & \\
\hline Sri Lanka & $\begin{array}{c}9.39 \\
(3.7)\end{array}$ & $\begin{array}{c}3.82 \\
(2.4)\end{array}$ & $\begin{array}{c}6.56 \\
(4.1)\end{array}$ & $\begin{array}{c}7.60 \\
(3.6)\end{array}$ & \\
\hline Thailand & $\begin{array}{c}21.64 \\
(3.5)\end{array}$ & $\begin{array}{c}17.85 \\
(8.5)\end{array}$ & $\begin{array}{c}6.02 \\
(7.4)\end{array}$ & $\begin{array}{l}2.06 \\
(0)\end{array}$ & \\
\hline Vietnam & & & $\begin{array}{c}14.63 \\
(6.1)\end{array}$ & $\begin{array}{r}3.80 \\
(5.4) \\
\end{array}$ & 2.00 \\
\hline South Asia & $\begin{array}{c}49.15 \\
(3.1)\end{array}$ & $\begin{array}{c}43.15 \\
(3.5)\end{array}$ & $\begin{array}{c}40.10 \\
(3.0)\end{array}$ & $\begin{array}{c}34.40 \\
(3.4)\end{array}$ & $\begin{array}{c}31.30 \\
(4.0)\end{array}$ \\
\hline Latin America \& & 10.75 & 11.10 & 11.30 & 10.60 & 9.50 \\
\hline Caribbean & $(-1.6)$ & $(0)$ & $(1.8)$ & $(1.6)$ & $(0.5)$ \\
\hline Sub-Saharan Africa & 43.95 & 45.70 & 44.10 & 45.65 & 46.40 \\
\hline
\end{tabular}

Source: Pasha and Palanivel 2004.

Table 3 makes interesting reading. The sharpest drop in poverty and the highest growth rates of per capita GDP have been observed in China and, to an extent, in Thailand. India's per capita GDP growth has been hovering around the 4 per cent mark (and has accelerated of late) but the impact of such growth on poverty has not been very impressive. Despite acceleration in per capita GDP growth rates, poverty has stagnated in Bangladesh. In Lao poverty has sharply increased despite per capita GDP growth in excess of 3.5 per cent. With lower growth rates poverty in the Philippines has fallen more sharply whereas a slackening of growth has led to a mild rise in poverty in Sri Lanka. Although Pakistan has demonstrated reductions in poverty, South Asia, despite per capita GDP growth rates of over 3 per cent a year since 1981 and 4 per cent since 
2001, has shown only a marginal decline in the headcount measure of poverty (less than 10 per cent from 40.10 to 31.30) over the period 1991-2003 - the first 13 years of the period over which the MDG are to be attained. Thus if MDG1 is to be attained by 2015 South Asia's Head count ratio must fall by a further 19 points in 12 years, i.e., at more than double the rate over the period 1991-2003. This will be a tall ask unless economic growth rises sharply in these countries.

It is possible to estimate the required acceleration in economic growth in some of these countries in order to attain MDG1. Table 4 depicts the poverty elasticity of growth (response of poverty an increase in the rate of economic growth) in select Asian countries.

Table 4: Growth Elasticity of Poverty in Different Countries in Different Decades

\begin{tabular}{|l|c|c|c|}
\hline \multicolumn{1}{|c|}{ Country } & 1970s & 1980s & 1990s \\
\hline Bangladesh & - & -0.29 & -0.81 \\
\hline Cambodia & - & - & 2.31 \\
\hline China & -0.18 & -1.26 & -1.09 \\
\hline India & -2.15 & -0.60 & -0.77 \\
\hline Indonesia & -1.33 & -1.35 & 0.72 \\
\hline Lao PDR & - & - & -1.37 \\
\hline Malaysia & -1.26 & -1.36 & 0.63 \\
\hline Mongolia & - & - & n.a \\
\hline Nepal & - & 0.33 & 0.27 \\
\hline Pakistan & -2.73 & -0.38 & 2.01 \\
\hline Philippines & -0.07 & n.a & -2.25 \\
\hline Sri Lanka & -0.30 & -2.28 & 1.24 \\
\hline Thailand & -1.02 & 0.10 & -0.63 \\
\hline Vietnam & - & - & -1.18 \\
\hline
\end{tabular}

Source: Pasha and Palanivel (2004)

In several of these countries poverty does not seem to decline with growth. If we take figures for the 1990s we find that the poverty elasticity of growth is positive in Cambodia, Indonesia, Malaysia, Nepal, Pakistan and Sri Lanka. Only in China, India, Lao PDR, Philippines, Thailand and Vietnam is this elasticity negative indicating that for these countries higher growth will lower poverty. Proximate calculations based on the Poverty elasticity of growth for the 1990s indicate that during 1990-2015 Bangladesh, China, India, Lao PDR, Philippines, Thailand and Vietnam should grow at 6.01 per cent, 4.6 per cent, 6.5 per cent, 3.6 per cent, 2.22 per cent, 7.94 per cent, and 4.24 per cent, respectively, in order to reach MDG1 by 2015. The computed magnitudes are required average annual growth rates for the period 1990-2015. Since there has already been a shortfall in this regard in some of these countries the acceleration in economic growth for the period remaining in the MDG horizon (2015) would correspondingly have to be higher. For some of these countries poverty elasticity of growth needs to be improved substantially. 


\section{Short Run Economic Growth Prospects in the Asia Pacific region}

Immediate prospects for a sharp rise in economic growth in 2006 are not very bright as growth prospects have moderated in 2006 as compared to 2005. At least since the trough of the global business cycle in 2001 much of the economic buoyancy in developing countries has resulted from high export prices. Non-oil commodity prices are now on a downward trend in real terms. A number of other factors support the view that commodity price fuelled rises in exports may not sustain such GDP growth rates for long. For instance, economic growth has already started slowing down in the major OECD countries due to a number of factors. There have been fifteen successive increases in the Federal Reserve's key interest rate, European interest rates have also been rising and Japanese interest rates are expected to rise soon. Adding to these are inflationary pressures from rising petroleum and commodity prices which show no immediate signs of abating. Other risk factors include macroeconomic imbalances arising from the high current account deficit (over $\$ 800$ billion in 2005) and high budget deficit in the US and the global slackness in non-real estate investment.

Furthermore although a key engine of recent rapid economic growth - international trade continues to expand rapidly - at about twice the pace of global output - the outlook for further liberalisation of world trade is uncertain after the Hong Kong Ministerial meeting in December 2005. At the same time there are indications of a trend towards renewed protectionism. Hence rapid expansion of international trade in the period up to 2015 cannot be taken for granted.

\section{Domestic Resources for Acceleration of Growth}

Having provided a brief account of the outlook for economic growth in the developing countries and underscored the need to enhance rates of economic growth in the Asia Pacific region, we now examine the availability of resources in the developing countries of the Asia Pacific region as a prelude to examining the prospects for enhancing such resource availability in the next section. For many of the large and densely populated developing countries of the Asia-Pacific region domestic resources for investment are more significant for purposes of investment than foreign sources of investment.

The current availability of domestic resources for domestic investment, however, is not uniformly promising. The global investment rate has been on a long-term declining trend, reaching a nadir in 2002 after which there has been only a slight recovery. In 2005 global investment was still below 22 per cent of global GDP. Thus it is not appropriate to conceive of the current situation as a global savings glut but one of deficient investment. In Tables 5, 6, 7 and 8 we present data on savings, gross domestic capital formation and gross domestic fixed capital formation, respectively, for major countries in Asia-Pacific and some groups of countries. 
R. Jha \& T. Palanivel

Table 5: Gross Domestic Saving Rates (Per Cent of GDP)

\begin{tabular}{lcrrrc}
\hline Countries/Regions & Average & Average & Average & Average & Average \\
& $1981-85$ & $1986-90$ & $1991-95$ & $1996-00$ & $2001-03^{b}$ \\
\hline Bangladesh & 7.60 & 9.40 & 12.58 & 15.65 & 17.64 \\
Bhutan & 9.16 & 18.87 & 31.86 & 25.29 & 29.89 \\
Cambodia & & 2.28 & 1.30 & 1.30 & 12.73 \\
China & 34.04 & 35.98 & 40.76 & 41.31 & 43.74 \\
Fiji & 18.26 & 16.19 & 10.34 & 10.26 & 20.31 \\
India & 19.62 & 21.89 & 22.93 & 21.04 & 22.14 \\
Indonesia & 30.11 & 31.90 & 32.38 & 26.62 & 22.86 \\
Iran, Islamic Rep. & 21.53 & 22.11 & 25.71 & 30.21 & 41.07 \\
Korea, Rep. & 26.96 & 35.50 & 35.10 & 35.72 & 31.33 \\
Lao PDR a & 1.96 & 0.11 & 11.88 & 12.94 & 19.23 \\
Malaysia & 28.12 & 33.31 & 37.85 & 46.02 & 42.24 \\
Maldives & & & 46.75 & 46.04 & 47.56 \\
Mongolia & 24.05 & 11.60 & 15.83 & 16.17 & 16.23 \\
Myanmar & 13.51 & 9.88 & 12.78 & 12.23 & \\
Nepal & 10.66 & 10.47 & 11.47 & 14.18 & 14.08 \\
Pakistan & 7.18 & 10.29 & 16.37 & 14.54 & 14.70 \\
Papua New Guinea & 10.04 & 14.35 & 31.46 & 24.43 & \\
Philippines & 21.52 & 19.24 & 16.32 & 17.01 & 17.52 \\
Singapore & 43.76 & 40.63 & 46.80 & 50.77 & 45.06 \\
Sri Lanka & 13.56 & 12.51 & 15.08 & 17.72 & 15.33 \\
Thailand & 24.35 & 30.78 & 35.76 & 34.29 & 31.23 \\
Vietnam & & 4.75 & 14.61 & 22.19 & 28.21 \\
\hline East Asia \& Pacific & 31.65 & 33.20 & 37.33 & 37.72 & 39.17 \\
South Asia & 17.02 & 19.22 & 21.04 & 19.76 & 20.65 \\
Latin America \& Caribbean & 22.80 & 22.92 & 19.45 & 19.76 & 20.08 \\
Middle East \& North Africa & 24.78 & 17.64 & 20.06 & 23.72 & 29.18 \\
Sub-Saharan Africa & 18.75 & 19.24 & 15.85 & 16.54 & 18.10 \\
Europe \& Central Asia & & 28.82 & 24.57 & 21.43 & 22.28 \\
Least developed & 5.33 & 7.68 & 7.09 & 11.16 & 13.03 \\
countries (UN classification) & 15.46 & 17.10 & 18.46 & 18.32 & 19.89 \\
Low income & 26.03 & 26.62 & 26.05 & 25.99 & 27.24 \\
Middle income & 22.47 & 21.72 & 22.05 & 20.06 \\
High income & & & & & \\
\hline
\end{tabular}

Notes: a: Data for Lao PDR missing for 1981, 1982, 1983, 1989, 1990, 1991, 1992, 1993, and 1994. b. For the period 2001-03 missing data are as follows: Bhutan (2003), Fiji (2002, 2003), Myanmar (2002, 2003, 2003), High Income Countries (2003), High Income OECD (2003) and World (2003).

Source: WDI 2005 
Resource Augmentation for Meeting the MDGs in the Asia-Pacific Region

Table 6: Gross Capital Formation (Per Cent of GDP)

\begin{tabular}{|c|c|c|c|c|c|}
\hline Countries/Regions & Av1981-1985 & Av1986-1990 & Av1991-1995 & Av1996-2000 & Av2001-2003 \\
\hline Bangladesh & 16.93 & 16.56 & 17.93 & 21.51 & 22.84 \\
\hline Bhutana & 40.10 & 34.89 & 43.81 & 41.54 & 42.67 \\
\hline Cambodiab & & 9.51 & 11.42 & 15.20 & 19.63 \\
\hline China & 34.35 & 36.28 & 39.25 & 37.85 & 39.50 \\
\hline Fiji c & 23.80 & 14.97 & 14.31 & 12.22 & 13.72 \\
\hline India & 21.80 & 23.35 & 23.38 & 22.41 & 22.80 \\
\hline Indonesia & 28.11 & 30.36 & 30.90 & 21.34 & 17.30 \\
\hline Iran, Islamic Rep. & 21.44 & 23.81 & 27.62 & 26.71 & 35.46 \\
\hline Korea, Rep. & 28.61 & 31.38 & 36.40 & 31.99 & 30.16 \\
\hline Lao PDR ${ }^{d}$ & 6.61 & 10.21 & 26.00 & 24.89 & 21.49 \\
\hline Malaysia & 30.85 & 25.67 & 39.44 & 32.16 & 25.71 \\
\hline Maldivese & & & 31.29 & 30.74 & 28.60 \\
\hline Nepal & 19.12 & 20.68 & 22.23 & 24.44 & 24.54 \\
\hline Pakistan & 18.69 & 18.75 & 19.63 & 17.24 & 15.79 \\
\hline Papua New Guinea ${ }^{\dagger}$ & 27.13 & 23.02 & 22.37 & 20.04 & \\
\hline Philippines & 24.41 & 19.58 & 22.41 & 21.74 & 20.31 \\
\hline Singapore & 46.63 & 36.08 & 34.98 & 34.46 & 25.32 \\
\hline Sri Lanka & 27.09 & 22.81 & 25.09 & 25.80 & 23.88 \\
\hline Thailand & 28.78 & 32.55 & 41.03 & 27.85 & 24.79 \\
\hline Vietnam ${ }^{\mathrm{h}}$ & & 14.61 & 21.92 & 28.54 & 31.53 \\
\hline East Asia \& Pacific & 32.51 & 33.35 & 37.16 & 34.07 & 34.45 \\
\hline South Asia & 21.19 & 22.25 & 22.57 & 21.92 & 22.11 \\
\hline Latin America \& Caribbean & 20.34 & 20.48 & 20.50 & 21.26 & 19.60 \\
\hline Middle East \& North Africa & 27.24 & 23.08 & 23.02 & 21.73 & 22.84 \\
\hline Sub-Saharan Africa & 20.91 & 18.03 & 17.57 & 18.03 & 18.05 \\
\hline Europe \& Central Asiai & & 29.27 & 24.53 & 22.70 & 22.15 \\
\hline $\begin{array}{l}\text { Least developed } \\
\text { countries (UN classification) }\end{array}$ & 15.79 & 15.77 & 17.10 & 19.73 & 20.82 \\
\hline Low income & 20.02 & 20.67 & 21.27 & 21.24 & 21.70 \\
\hline Middle income & 25.63 & 26.05 & 26.54 & 25.34 & 24.79 \\
\hline High incomej & 22.75 & 22.77 & 21.37 & 21.81 & 21.59 \\
\hline
\end{tabular}

Notes: a: Data not available for 2003;

b: data not available up to 1987 ;

c: data not available for 2002,2003

d: data not available up to 1983, 1989, 1990, 1991, 1992, 1993, 1994

e: data not available up to 1994

f: data not available for 2000, 2001, 2002, 2003

g: no data available

h: data not available up to 1985

i: data not available for 1988

j: data not available for 2003.

Source: WDI 2005 
R. Jha \& T. Palanivel

Table 7: Gross Domestic Fixed Capital Formation (Per Cent of GDP)

\begin{tabular}{|c|c|c|c|c|c|}
\hline Countries/Regions & $\begin{array}{l}\text { Average } \\
1981-85\end{array}$ & $\begin{array}{l}\text { Average } \\
1986-90\end{array}$ & $\begin{array}{l}\text { Average } \\
1991-95\end{array}$ & $\begin{array}{l}\text { Average } \\
1996-00\end{array}$ & $\begin{array}{l}\text { Average } \\
\text { 2001-03 }\end{array}$ \\
\hline Bangladesh & 16.93 & 16.56 & 17.93 & 21.51 & 22.83 \\
\hline Bhutana & 37.14 & 36.18 & 42.42 & 41.87 & 39.31 \\
\hline Cambodiab & & 9.59 & 11.07 & 14.67 & 19.47 \\
\hline China & 28.37 & 28.76 & 33.39 & 35.16 & 38.75 \\
\hline Fijic & 21.27 & 13.41 & 12.97 & 10.99 & 13.71 \\
\hline India & 19.45 & 21.90 & 22.45 & 21.96 & 22.22 \\
\hline Indonesia & 23.88 & 26.24 & 27.01 & 25.06 & 21.65 \\
\hline Iran, Islamic Rep. & 19.28 & 14.16 & 21.74 & 23.84 & 27.48 \\
\hline Korea, Rep. & 28.83 & 31.38 & 37.17 & 32.85 & 30.44 \\
\hline Lao PDRd & 6.61 & 10.21 & 26.00 & 26.86 & \\
\hline Malaysia & 32.74 & 26.83 & 39.14 & 31.98 & 25.54 \\
\hline Maldivese & 27.07 & 35.51 & 31.49 & 30.74 & 28.60 \\
\hline Nepal & 18.25 & 18.37 & 20.39 & 20.87 & 19.52 \\
\hline Pakistan & 16.79 & 17.11 & 18.08 & 15.74 & 15.57 \\
\hline Papua New Guineaf & 26.36 & 22.92 & 21.30 & 14.65 & \\
\hline Philippines & 25.42 & 19.01 & 22.12 & 21.78 & 19.97 \\
\hline Singapore & 45.71 & 32.92 & 34.16 & 35.74 & 29.29 \\
\hline Sri Lanka & 27.28 & 22.63 & 24.71 & 25.71 & 23.78 \\
\hline Thailand & 27.83 & 31.82 & 40.30 & 28.00 & 23.97 \\
\hline Vietnam ${ }^{\mathrm{h}}$ & & 13.17 & 24.84 & 26.68 & 29.52 \\
\hline East Asia \& Pacific & 27.95 & 27.93 & 32.77 & 32.54 & 34.23 \\
\hline South Asia & 19.18 & 20.95 & 21.66 & 21.37 & 21.58 \\
\hline Latin America \& Caribbean & 19.55 & 19.78 & 19.03 & 19.57 & 18.61 \\
\hline Middle East \& North Africa & 25.24 & 21.47 & 21.30 & 20.72 & 20.63 \\
\hline Sub-Saharan Africa & 20.62 & 17.70 & 17.29 & 17.62 & 17.59 \\
\hline Europe \& Central Asiai & & 24.50 & 21.83 & 21.69 & 20.49 \\
\hline $\begin{array}{l}\text { Least developed } \\
\text { countries (UN classification) }\end{array}$ & 15.60 & 15.41 & 16.93 & 19.55 & 20.72 \\
\hline Low income & 18.30 & 19.70 & 20.65 & 20.91 & 21.34 \\
\hline Middle income & 23.53 & 23.42 & 24.00 & 23.88 & 23.74 \\
\hline High incomej & 22.39 & 22.30 & 21.11 & 21.37 & 21.70 \\
\hline
\end{tabular}

Notes: a: Data not available for 2003 ;

b: data not available up to 1987 ;

c: data not available for 2002, 2003

d: data not available up to 1983, 1989, 1990, 1991, 1992, 1993, 1994

e: data not available up to 1994

f: data not available for 2000, 2001, 2002, 2003

g: no data available

h: data not available up to 1985

i: data not available for 1988

j: data not available for 2003.

Source: WDI 2005

Savings rates have gone up in Bangladesh, Cambodia, China, Fiji, Lao, Malaysia, Maldives and Vietnam. However savings rates have stagnated in India, Nepal, Pakistan, the Philippines and Sri Lanka and actually fallen in Indonesia, Mongolia, 
Papua New Guinea and Thailand. Although the savings rate has picked up for the least developed and low income countries, the rise for low and middle income countries is small in magnitude. South Asian savings rates have stagnated; the global average was only marginally above 21 per cent. In 2001-03 and down from 1996-00.

Trends in capital formation have followed the trend in savings for most of the countries. The investment rates of Bangladesh, Cambodia, China, Nepal and Vietnam have shown a trend increase. India's investment rate has largely stagnated and increased only marginally during 2001-03. Investment rates in Pakistan, Philippines and Thailand have been falling, although Thailand's investment rate is at a high level. As a group the investment rate of low-income countries has stagnated below 22 per cent of GDP whereas that of low and middle income countries has also stagnated albeit at a slightly higher level. South Asian and World investment rates have also been stagnant at 22 per cent since 1991.

With relatively stagnant investment rates GDP growth rates can be boosted by boosting resources for investment growth and by falling Incremental Capital Output Ratios (ICOR). We inquire into prospects for the former in the section below. In Table 8 we present evidence on the movement of ICOR in some major countries in the Asia Pacific region.

Table 8: Incremental Capital Output Ratios in Major Asia-Pacific Countries

\begin{tabular}{lcccccccccccccc}
\hline Period & B'Desh & Bhutan & China & India & Indosa & Iran & Korea & Malays & Mym & Pak & Philli & Sing & Thai & Viet \\
\hline $\begin{array}{l}\text { Average } \\
\text { 1982-86 }\end{array}$ & 4.1 & 6.6 & 3.7 & 4.9 & 4.6 & & 12.5 & 9.9 & 4.2 & 3.9 & 9.5 & 8.7 & 5.7 & 2.2 \\
$\begin{array}{l}\text { Average } \\
\text { 1987-91 }\end{array}$ & 5.4 & 9.6 & 6.0 & 7.9 & 4.2 & 2.1 & 6.8 & 3.9 & 4.8 & 4.0 & 4.8 & 3.9 & 3.7 & 3.8 \\
$\begin{array}{l}\text { Average } \\
\text { 1992-96 }\end{array}$ & 4.1 & 7.1 & 3.6 & 3.8 & 4.5 & 6.5 & 13.1 & 5.0 & 3.3 & 5.9 & $6.5^{c}$ & 4.2 & 5.7 & 5.3 \\
$\begin{array}{l}\text { Average } \\
\text { 1997-2001 }\end{array}$ & 4.5 & 5.2 & 5.2 & 4.9 & 9.9 & 6.9 & 7.7 & $4.2^{\mathrm{b}}$ & 4.2 & 9.3 & 6.0 & 4.7 & 6.3 & \\
$\begin{array}{l}\text { Average } \\
\text { 2002-03 }\end{array}$ & 5.5 & & 5.2 & 4.8 & 4.8 & 3.2 & 17.9 & & & 4.5 & 5.3 & 11.0 & 3.8 & \\
\hline
\end{tabular}

N.B. a: excluding 1992, b: excluding 2001; c: excluding 1992

Source: Computed from WDI (2005)

There does not seem to be any significant downward trend in the ICORs of many large countries. In the case of Bangladesh the ICOR has an upward trend. Bhutan's ICOR has dropped but it is too small a country to have much significance. China's ICOR has gone up since 1992 and so has India's. Indonesia's ICOR has remained relatively unchanged and Korea's, Vietnam's and Singapore's have increased. There has been a downward tend in the ICORs of Pakistan, Philippines and Thailand. Thus prospects for raising growth rates through significant drops in ICORs appear remote.

Several explanations for the relatively high ICORs in the developing countries of the Asia-Pacific region abound none more compelling than the fact that the share of agriculture in GDP has been declining steadily in many of these countries. This is depicted in Table A1 (Appendix). The movement of sectoral shares is depicted in Table A2 of the Appendix. 
Given the actual growth performance, the required growth performance to attain MDG1 and the ICOR it is possible to compute the boost in investment required to attain this required growth rate. In Bangladesh and India, for example the investment rate has to go up by 4.4 per cent of GDP and 3.36 per cent of GDP respectively.

Such sharp rises in the rate of investment should be accompanied by corresponding rises in the savings rates. If the gap between savings and investment widens further current account gaps would increase, creating further difficulties. Hence any effort to raise rates of investment in these countries in order to raise growth rates would need to involve raising the savings rates. Now, higher growth rates would themselves act as stimulants of private saving (Loayza et al., 2000). ${ }^{2}$ The anticipated demographic transition in some of these countries with the proportion of the young in the population rising could also boost savings. However, an important condition must be that the government does not dissave through high budgetary deficits. It is entirely likely that higher private saving may be accompanied by higher public dissaving thus leaving no additional resources for enhancing investible resources.

With this as background it becomes imperative to ask how resources for development can be augmented so that it may be possible to attain the MDGs by 2015 .

\section{$\underline{\text { IV. Inadequate Resources for Development in the Asia Pacific region }}$}

We now take up the issue of augmenting resources for development. The analysis takes as a maintained hypothesis that a more efficient tax system would not only lead to higher tax revenues but also to higher savings (and hence investment) since a more streamlined tax structure would reduce disincentives for savings and investment.

Table 9 depicts trends in total revenue and tax revenue in the major Asia Pacific countries and major regions of the world.

\section{Tax and other Sources of Public Revenue}

Most of the large developing countries in the Asia Pacific region have low tax/GDP and public revenue/GDP ratios compared to developed countries. Bhutan and Cambodia have shown upward trends in public revenue and tax collection. Although India's public revenue collections have gone up in recent times, they are still below the level for 1986-90. At the same time, tax collections have stagnated, indeed, dropped off in some periods. Indonesia and Pakistan show similar trends. In contrast Korea's revenue figures are close to OECD levels. Malaysia, a middle income country shows similar trends whereas tax and revenue figures are high but declining for Sri Lanka, Thailand and Vietnam. In terms of country groups South Asia shows a declining trend in public revenue. Thus, without major tax reforms it does not appear likely that developing countries of the Asia Pacific region will be able to raise public resources sufficiently to raise growth rates required to attain the MDGs.

\footnotetext{
${ }^{2}$ Also see Figures 1 to 5 in the Appendix.
} 
Resource Augmentation for Meeting the MDGs in the Asia-Pacific Region

Table 9: Trends in Revenue: 1981-2004

\begin{tabular}{|c|c|c|c|c|c|c|}
\hline \multirow{2}{*}{ Countries/ Region } & \multicolumn{3}{|c|}{ Revenue Ratio } & \multicolumn{3}{|c|}{ Tax Ratio } \\
\hline & $90-94$ & $99-2003$ & Change & $90-94$ & $99-2003$ & Change \\
\hline Bangladesh & 13.46 & 15.38 & 1.92 & 6.52 & 7.72 & 1.20 \\
\hline Bhutan & 20.39 & 20.23 & -0.16 & 6.7 & 10.57 & 3.87 \\
\hline India & 18.04 & 18.26 & 0.22 & 14.38 & 14.48 & 0.1 \\
\hline Maldives & & 31 & & 13 & 13.85 & 0.85 \\
\hline Nepal & 9.12 & 11.63 & 2.51 & 6.99 & 9.05 & 2.06 \\
\hline Pakistan & 18.19 & 14.37 & -3.81 & 13.4 & 11.4 & -2.01 \\
\hline Sri Lanka & 20.20 & 16.68 & -3.52 & 18.03 & 14.26 & -3.77 \\
\hline South Asia & 16.57 & 18.22 & 4.02 & 11.29 & 11.62 & 0.33 \\
\hline Cambodia & 5.46 & 10.51 & 5.05 & 3.65 & 7.48 & 3.83 \\
\hline China & 13.44 & 16.45 & 3.01 & 12.93 & 15.33 & 2.39 \\
\hline Indonesia & 17.42 & 16.80 & -0.61 & 15.91 & 10.62 & -5.3 \\
\hline Korea, Rep. & 17.18 & 22.79 & 5.6 & 14.86 & 18.04 & 3.17 \\
\hline Lao PDR & 10.91 & 11.66 & 0.75 & 7.97 & 9.4 & 1.42 \\
\hline Malaysia & 25.11 & 21.58 & -3.53 & 18.75 & 16.43 & -2.32 \\
\hline Mongolia & 32.99 & 35.54 & 2.55 & 27.96 & 26.47 & -1.49 \\
\hline Myanmar & 8.18 & 4.56 & -3.63 & 5.16 & 2.12 & -3.05 \\
\hline Philippines & 17.85 & 15.14 & -2.7 & 15.15 & 13.35 & -1.81 \\
\hline Singapore & 33.42 & 26.71 & -6.71 & 16.48 & 14.56 & -1.92 \\
\hline Thailand & 18.46 & 15.76 & -2.7 & 16.88 & 14.05 & -2.83 \\
\hline Vietnam & 18.50 & 20.13 & 1.63 & 14.34 & 17.27 & 2.94 \\
\hline East Asia & 18.24 & 18.14 & -0.11 & 14.17 & 13.76 & -0.41 \\
\hline Fiji & 26.57 & 25.39 & -1.18 & 21.17 & 20.48 & -0.68 \\
\hline Papua New Guinea & 23.18 & 21.30 & -1.88 & 19.04 & 19.73 & 0.69 \\
\hline Samoa & 41.09 & 24.50 & -16.59 & 31.44 & 21.04 & -10.39 \\
\hline Vanuatu & 24.02 & 20.22 & -3.8 & 19.43 & 17.69 & -1.74 \\
\hline Pacific & 28.72 & 22.85 & -5.86 & 22.77 & 19.74 & -3.03 \\
\hline Asia and the Pacific & 19.69 & 18.98 & 0.15 & 14.79 & 14.15 & -0.64 \\
\hline
\end{tabular}

Source: Palanivel (2006)

\section{Reasons for Inadequate availability of public resources in Developing Countries}

We discus several reasons for the poor performance of public revenue in developing countries.

\section{(i) Corruption and the Shadow Economy}

One of the principal reasons why public revenues and tax/GDP rates are not higher in developing countries is because of the existence of substantial shadow economies, often supported by inefficient and highly distortionary tax structures. In table 10 below we present evidence of the shadow economies in some of the major countries of the region. 
Table 10: The Size of the Shadow Economy in Twenty-eight Asian Countries

\begin{tabular}{|c|c|c|c|c|}
\hline \multirow[t]{2}{*}{ No. } & \multirow[t]{2}{*}{ Country } & \multicolumn{3}{|c|}{$\begin{array}{l}\text { Shadow Economy in percentage of official GDP using the } \\
\text { DYMIMIC and Currency Demand Method }\end{array}$} \\
\hline & & 1999-00 & 2001-02 & $2002-03$ \\
\hline 1. & Bangladesh & 35.6 & 36.5 & 37.7 \\
\hline 2. & Bhutan & 29.4 & 30.5 & 31.7 \\
\hline 3. & Cambodia & 50.1 & 51.3 & 52.4 \\
\hline 4. & Hong Kong, China & 16.6 & 17.1 & 17.2 \\
\hline 5. & India & 23.1 & 24.2 & 25.6 \\
\hline 6. & Indonesia & 19.4 & 21.8 & 22.9 \\
\hline 7. & Iran & 18.9 & 19.4 & 19.9 \\
\hline 8. & Israel & 21.9 & 22.8 & 23.9 \\
\hline 9. & Jordan & 19.4 & 20.5 & 21.6 \\
\hline 10. & S. Korea & 27.5 & 28.1 & 28.8 \\
\hline 11. & Kuwait & 20.1 & 20.7 & 21.6 \\
\hline 12. & Lebanon & 34.1 & 35.6 & 36.2 \\
\hline 13. & Malaysia & 31.1 & 31.6 & 32.2 \\
\hline 14. & Mongolia & 18.4 & 19.6 & 20.4 \\
\hline 15. & Nepal & 38.4 & 39.7 & 40.8 \\
\hline 16. & Oman & 18.9 & 19.4 & 19.8 \\
\hline 17. & Pakistan & 36.8 & 37.9 & 38.7 \\
\hline 18. & Papua New Guinea & 36.1 & 37.3 & 38.6 \\
\hline 19. & Philippines & 43.4 & 44.5 & 45.6 \\
\hline 20. & Saudi Arabia & 18.4 & 19.1 & 19.7 \\
\hline 21. & Singapore & 13.1 & 13.4 & 13.7 \\
\hline 22. & Sri Lanka & 44.6 & 45.9 & 47.2 \\
\hline 23. & Syria & 19.3 & 20.4 & 21.6 \\
\hline 24. & Taiwan & 25.4 & 26.6 & 27.7 \\
\hline 25. & Thailand & 52.6 & 53.4 & 54.1 \\
\hline 26. & Turkey & 32.1 & 33.2 & 34.3 \\
\hline 27. & UAE & 26.4 & 27.1 & 27.8 \\
\hline 28. & Yemen, Republic & 27.4 & 28.4 & 29.1 \\
\hline \multicolumn{2}{|c|}{ Unweighted Average 28 Asian Countries } & 28.5 & 29.5 & 30.4 \\
\hline \multicolumn{2}{|c|}{ Unweighted Average 37 African Countries } & 41.3 & 42.3 & 43.2 \\
\hline \multirow{2}{*}{\multicolumn{2}{|c|}{$\begin{array}{l}\text { Unweighted Average } 21 \text { Central } \\
\text { and South American Countries } \\
\text { Unweighted Average } 25 \text { East and Central } \\
\text { European and Former Soviet Countries }\end{array}$}} & 41.1 & 42.2 & 43.4 \\
\hline & & 38.1 & 39.1 & 40.1 \\
\hline \multicolumn{2}{|c|}{ Unweighted Average 21 OECD Countries } & 16.8 & 16.7 & 16.3 \\
\hline
\end{tabular}

Source: Schneider (2005)

The share of the shadow economy in GDP is high for the developing countries of Asia and the Pacific. Indeed the weighted average for 28 Asian countries has gone up during the period 1999-00 to 2002-03. Underpinning this are steady rises in the sizes of the shadow economies of major countries such as India, Indonesia, Thailand, Sri Lanka, Pakistan, Papua New Guinea and Philippines. 
The sizes of the shadow economies of these countries do not reveal the true extent of their informal economies. For instance, the 2002-03 Economic Survey of the Government of India suggested that as much as 91 per cent of India's labour force worked in the informal sector. Clearly, some of the output from the informal sector is part of the official GDP. Similarly, the relationship between corruption and the shadow economy are quite complex and vary between developed and developing countries (Dreher and Schneider 2006). ${ }^{3}$ Typically in developed economies bribing government officials when detected engaging in the shadow economy is rarely an option. It is likely, therefore, that in such countries corruption might be independent of the shadow economy. However as Choi and Thum (2005) and Dreher et al. (2005) show the shadow economy in developed economies can mitigate government-induced distortions, so that corruption and the shadow economy could also be substitutes. In developed countries entrepreneurs do not have to pay bribes demanded by officials and can always bring corrupt officials to court. Hence, entrepreneurs can choose for themselves whether to pay a bribe or operate underground. In developing counties, however, such prosecution of corrupt officials may be difficult to pursue. On the contrary officials may ask for bribes to not report underground activity. In such cases, corruption and he shadow economy may turn out to be complements rather than substitutes. Dreher and Schneider (2006) provide ${ }^{4}$ econometric evidence to support this difference in the relationship between the shadow economy and corruption between developed and low and middle income countries. They also find a positive impact of regulation on the shadow economy. Both corruption and the shadow economy are significantly smaller with better rule of law, greater governmental effectiveness, more judicial independence, impartial courts and higher integrity of the legal system. These results thus provide a policy handle on measures that could be undertaken to reduce the size of the shadow economy and thereby boost tax/GDP ratios.

\section{(ii) Capital Flight}

Developing countries are often subject to substantial outflow of scarce capital. Various definitions of capital flight have been used in recent times. A popular measure used is that part of the outflow of resident capital which is motivated by economic and political uncertainty (Schneider 2003, Kant 2002). This broad definition envisages capital flight to be a real resource transfer motivated by such uncertainty.

To make this broad definition operational some refinements are needed. In particular capital today is highly mobile internationally and responds to increasing opportunities created by increasing integration of world financial markets and the development of new financial instruments, transport and communications. Furthermore foreign trade has also increased in volume and importance in recent years. The private sector can

\footnotetext{
${ }^{3}$ Auriol and Warlters (2005) argue that the relatively large size of the informal economy in developing countries as opposed to developed countries is a direct result of government policy to increase tax revenue. The government raises barriers to entry into the formal sector thus raising market power and hence rents for entrants for those in the formal sector. These rents can then be taxed through corporate profits tax. Auriol and Warlters also provide empirical evidence from 64 countries to substantiate these claims.

${ }^{4}$ Dreher and Schneider (2006) use data on actual corruption as opposed to perceptions of corruption. This route has some distinct advantages. First, as Mocan 2004) shows perceived corruption is completely unrelated to actual corruption when other factors are controlled for. Furthermore perceived corruption is unrelated to bribery (Weber Abramo 2005).
} 
acquire external claims in the normal course of international business activity and also while making adjustments in portfolio composition in response to a change in scale variables such as a change in wealth or return variables such as changes in inflation, exchange and interest rates. Nevertheless, this broad definition of capital flight as that part of flows which are motivated by political and economic uncertainty stresses the point that outflows of capital can take place even if they are not motivated by flight factors. It also allows for the possibility that capital flight need not be always be a real resource transfer but can be one side of a two-way flow or both, under certain conditions.

In Table 11 we report on the existing magnitudes of capital flight in major regions of the world with a preponderance of developing countries.

Table 11: Magnitude and Burden of Capital Flight: Average Flows for 1983-98

\begin{tabular}{lrrrrrrrr}
\hline & \multicolumn{2}{c}{ East Asia } & \multicolumn{2}{c}{ South Asia } & \multicolumn{2}{c}{ Sub-Saharan Africa } & \multicolumn{2}{c}{ Latin America } \\
\cline { 2 - 8 } Year & CF & CF to & CF & CF to & CF & CF to & CF & CF to \\
& (US \$bn) & GDP (\%) & (US \$bn) & GDP (\%) & (US \$bn) & GDP (\%) & (US \$bn) & GDP (\%) \\
\hline 1983 & 5 & 1.1 & 5 & 1.7 & -0.9 & -2.4 & 4 & 0.9 \\
1984 & 7 & 1.3 & 0.2 & 0.1 & 0.5 & 1.3 & 17 & 3.9 \\
1985 & 3 & 0.5 & 3 & 0.8 & 5 & 11.4 & 9 & 2.0 \\
1986 & 10 & 1.9 & 5 & 1.6 & 5 & 10.8 & -8 & -1.5 \\
1987 & 37 & 6.4 & 6 & 1.7 & 6 & 12.1 & 15 & 2.8 \\
1988 & 33 & 4.8 & -4 & -1.2 & -2 & -3.1 & -3 & -0.5 \\
1989 & 17 & 2.2 & 8 & 2.1 & 2 & 4.4 & 5 & 0.8 \\
1990 & 50 & 5.8 & -0.1 & -0.03 & 4 & 8.1 & 26 & 3.5 \\
1991 & 51 & 5.4 & 7 & 2.0 & 1 & 2.3 & 19 & 2.5 \\
1992 & 42 & 4.1 & 5 & 1.3 & -0.4 & -0.8 & 40 & 4.9 \\
1993 & 46 & 4.1 & 10 & 2.7 & -0.1 & -0.3 & 16 & 1.8 \\
1994 & 140 & 10.5 & 17 & 4.0 & 2 & 5.2 & 30 & 2.9 \\
1995 & 113 & 6.9 & -16 & -3.3 & 4 & 6.9 & 28 & 2.3 \\
1996 & 102 & 5.6 & -6 & -1.2 & 0.7 & 1.3 & 52 & 3.9 \\
1997 & 103 & 5.6 & -4 & -0.7 & -3 & -5.6 & 33 & 2.3 \\
1998 & 189 & 12.2 & 8 & 1.5 & 0.4 & 0.6 & 24 & 1.7 \\
\hline
\end{tabular}

N.B.: $\quad$ The table shows data for capital flight based on the residual method defined as change in debt + net foreign investment)- (current account deficit + changes in reserves.

Country groups are:

East Asia: China, Fiji, Indonesia, Korea, Papua New Guinea, Philippines, Samoa, Solomon Islands and Thailand. South Asia: Bangladesh, Bhutan, India, Pakistan, and Sri Lanka.

Sub-Saharan Africa: Botswana, Cameroon, Cote d'Ivoire, Ethiopia, Kenya, Mauritania, Mauritius, Mozambique, Swaziland and Uganda.

Latin America: Argentina, Barbados, Bolivia, Brazil, Chile, Colombia, Costa Rica, El Salvador, Jamaica, Nicaragua, Paraguay and Venezuela

Source: Hermes et al. (2002)

Table 12 reports the same information for selected individual countries in these regions. 
Resource Augmentation for Meeting the MDGs in the Asia-Pacific Region

Table 12: Individual Country Data on Capital Flight, Averages 1983-98

\begin{tabular}{|c|c|c|c|}
\hline \multicolumn{4}{|l|}{ East Asia } \\
\hline Country & Period & CF (US\$mn.) & CF/GDP (\%) \\
\hline \multirow{2}{*}{ China } & $1983-98$ & 4,827 & 1.9 \\
\hline & $1990-98$ & 64,493 & 10.2 \\
\hline \multirow{2}{*}{ Fiji } & $1983-98$ & 33 & 3.0 \\
\hline & $1990-98$ & -33 & -1.9 \\
\hline \multirow{2}{*}{ Indonesia } & $1983-98$ & 2,864 & 3.4 \\
\hline & $1990-98$ & 9,389 & 6.7 \\
\hline \multirow{2}{*}{ Korea } & $1983-98$ & 5,989 & 4.0 \\
\hline & $1990-98$ & 11,323 & 3.2 \\
\hline \multirow{2}{*}{ Papua New Guinea } & $1983-98$ & -5 & 0.2 \\
\hline & $1990-98$ & 402 & 8.9 \\
\hline \multirow{2}{*}{ Philippines } & $1983-98$ & 115 & 0.6 \\
\hline & $1990-98$ & 1,978 & 3.3 \\
\hline \multirow{2}{*}{ Samoa } & $1983-98$ & 16 & 15.4 \\
\hline & $1990-98$ & 8 & 3.1 \\
\hline \multirow{2}{*}{ Solomon Islands } & 1983-98 & -2 & -0.1 \\
\hline & $1990-98$ & 14 & 4.7 \\
\hline \multirow{2}{*}{ Thailand } & $1983-98$ & 2,061 & 3.5 \\
\hline & $1990-98$ & 5,335 & 4.6 \\
\hline \multicolumn{4}{|l|}{ South Asia } \\
\hline \multirow{2}{*}{ Bangladesh } & $1983-98$ & 164 & 0.9 \\
\hline & $1990-98$ & -160 & -0.2 \\
\hline \multirow{2}{*}{ Bhutan } & $1983-98$ & -74 & -33.8 \\
\hline & $1990-98$ & -13 & -4.5 \\
\hline \multirow{2}{*}{ India } & $1983-98$ & 2,694 & 1.1 \\
\hline & $1990-98$ & 2,555 & 0.9 \\
\hline \multirow{2}{*}{ Pakistan } & $1983-98$ & 2,761 & 0.9 \\
\hline & $1990-98$ & -282 & -0.2 \\
\hline \multirow{2}{*}{ Sri Lanka } & $1983-98$ & 46 & 0.7 \\
\hline & $1990-98$ & 286 & 2.8 \\
\hline
\end{tabular}

Source: Hermes et al. (2002)

Capital flight seems to have increased in China, Indonesia, Papua New Guinea, the Philippines, Solomon Islands, Thailand and Sri Lanka. In other countries there appears to have been some decline. Nevertheless, the magnitudes of capital flight remain high. As a result, the stock of capital flight has remained high. This is shown in table 13 .

Table 13: Stock of Capital Flight, End of 1998

\begin{tabular}{lcc}
\hline Regions & $\begin{array}{c}\text { Capital Flight } \\
\text { (US\$ bn) }\end{array}$ & $\begin{array}{c}\text { Capital Flight to GDP in } \\
1998 \text { (per cent) }\end{array}$ \\
\hline East Asia & 947 & 60.9 \\
South Asia & 43 & 7.8 \\
Latin America & 309 & 22.0 \\
Sub-Saharan Africa & 25 & 41.3 \\
\hline
\end{tabular}

N.B. Stocks are found by adding up annual flows for 1983-98.

Source: Hermes et al. (2002) 
The high incidence of capital flight from developing countries begs the question of what can be done to reduce such outflows. To ascertain this one must come to grips with the determinants of capital flight. This issue is addressed in a recent paper by Cerra et al. (2005). They argue that capital flight undermines economic growth and the effectiveness of debt relief and foreign aid. The authors investigate the linkages between capital flight, debt accumulation, macroeconomic policies and institutional quality for 134 developing and transition economies including 22 Asian countries over the period 1970 to 2001 . The authors model the mutual dependence of capital flight and debt accumulation/foreign financing as:

Capital flight $=\mathrm{f}($ institutional quality, macro policies and conditions, foreign financing $)$

Debt accumulation/foreign financing $=\mathrm{g}$ (capital flight, institutional quality, other macro policies and conditions).

Institutional quality is approximated using variables such as the constraints on the powers of the executive and political confidence. Data on macro variables includes variables such as budget deficits, inflation, exchange rates, interest rtes and the like. Capital flight is defined using the residual method. Panel data estimation using two stage least squares (2SLS) techniques reveals that macroeconomic policy variables and conditions have a significant influence on capital flight, even after controlling for country effects and institutional quality. Institutional quality, particularly effective institutional constraints on executive power, has an independent and significant impact on capital flight. Furthermore capital flight is a mechanism by which institutional quality affects macroeconomic volatility. There is strong evidence to suggest the existence of a "revolving door" relationship between external financing and capital flight. Thus, developing and transition countries need to address the joint issues of poor institutional quality and unsound macroeconomic policies to reduce capital flight.

\section{(iii) Institutional Factors and Poor Tax Effort}

Another factor that leads to low tax yields in developing countries is inefficient tax design in these countries. In this context Bird et al. (2005) argue that poor tax/GDP ratio outcomes in developing countries are primarily the result of poor tax effort and institutional quality. In their view the fundamental problem of tax policy in developing countries is the Wicksellian one of raising the tax/GDP ratio from 10 to 15 per cent of GDP (which characterizes many developing countries) to the 25 to 30 per cent level characteristic of developed OECD countries.

Jha (2006) models the determinants of tax/GDP ratio in 13 developing countries (Asia pacific countries included were India, Indonesia, Malaysia, Sri Lanka and Thailand) over the period 1985-2002. A panel fixed effects regression of the log of the tax/GDP ratio against the log of per capita real income, a time and a constant for these countries over the period 1985-98 revealed interesting results.

$$
\operatorname{Ln}(\operatorname{tax} / G D P)=0.978-0.01064 * \text { time trend }+0.263401 * \ln \text { PC real income }
$$

$$
\text { (1.85) (-4.19) }
$$

$t$ - statistics are in parenthesis. The constant is significant at 6.6 percent and the time trend and per capita real income at 1 per cent. The F-statistic is highly significant. 
Thus there appears to be a declining trend in the response of tax collection. The elasticity of the tax/GDP ratio with respect to per capita real income is significant and has the right sign but is small in magnitude, although it is much larger than the coefficient on the time trend. It would appear, then, that without substantial tax reform, the tax/GDP ratio in developing countries is unlikely to reach the levels required to finance expenditures associated with OECD or middle-income type countries and maintain debt sustainability.

In their analysis Bird et al. argue that tax effort (measured as tax/GDP) depends both on "supply side factors" such as GDP per capita (as depicted in the equation above) as well as "demand side" factors such as institutional quality. Thus apart from their favourable impact on reducing capital flight institutional factors also affect tax effort in developing countries. But whereas Cerra et al. identify constraints on the powers of the executive as the principal institutional factor responsible for arresting capital flight, Bird et al identify a number of such factors that may be responsible for tax effort. Their basic empirical model is represented as:

$T E=h(Y, P O P, X M, N A G R, I N S T I T)$

where TE is the tax/GDP ratio, POP is population, $\mathrm{XM}$ is the ratio of exports plus imports to GDP, NAGR is non agriculture share of GDP and INSTIT is a measure of institutional quality. The last variable includes factors like a quality of governance index, a measure of international country risk, and indices of the size of the shadow economy, tax morale, inequality, decentralisation and some other control variables. This model is estimated using panel data for a number of countries and using the WDI 2003 database. The most significant result is that institutional factors matter significantly in determining tax effort. In particular quality of governance and the risk index perform well in explaining tax effort. Improving the quality of governance and improving a country's international risk rating are objectives - but not necessarily policy tools. Hence although this paper's contributions are of significance, this work needs to be extended to provide reasonable policy tool to augment tax/GDP ratios. ${ }^{5}$

The authors make the further important point that a sustainable tax system is one in which the benefits of public expenditure are linked to the taxes collected. Tax payers would be more willing to pay taxes provided they knew that the revenues so collected are being used productively to provide public services whose benefits the taxpayers can readily perceive. This points to the need for developing a more transparent fiscal arrangement whereby tax liabilities are linked in a transparent fashion to perceived public goods availability. An important agenda for policy research would be identifying the exact policy tools whereby this could be made possible.

\section{(iv) Inefficient Public Expenditure Policies}

Even if adequate public revenue were available there is no guarantee that expenditure policies will be such that adequate resources will be targeted towards public expenditure programs relevant to attaining the MDG.

\footnotetext{
${ }^{5}$ Jha et al. (1999) argue that it is inappropriate to conceive of the tax/GDP ratio as tax effort. Tax/effort should be measured as the remainder of tax/GDP from that which can be explained by such determinants. An advantage of the Jha et al. methodology is that it is possible to isolate policy tools to raise tax/GDP ratios. This methodology was applied within a sub national context in India and not across a sample of developing countries.
} 
Table 14 below depicts trends in public expenditure on education and health in select Asia Pacific developing countries and some country groups.

Table 14: Trends in Public Spending on Education and Health: 1981-2004

\section{(As a \% of GDP)}

\begin{tabular}{|c|c|c|c|c|c|c|c|c|c|c|}
\hline \multirow[b]{2}{*}{$\begin{array}{l}\text { Countries/ } \\
\text { Regions } \\
\end{array}$} & \multicolumn{5}{|c|}{ Education } & \multicolumn{5}{|c|}{ Health } \\
\hline & $\begin{array}{l}1981- \\
1985\end{array}$ & $\begin{array}{l}1986- \\
1990\end{array}$ & $\begin{array}{l}1991- \\
1995\end{array}$ & $\begin{array}{l}1996- \\
2000\end{array}$ & $\begin{array}{l}2001- \\
2004\end{array}$ & $\begin{array}{c}1981- \\
1985\end{array}$ & $\begin{array}{l}1986- \\
1990\end{array}$ & $\begin{array}{l}1991- \\
1995\end{array}$ & $\begin{array}{l}1996- \\
2000\end{array}$ & $\begin{array}{l}2001- \\
2004\end{array}$ \\
\hline Cambodia & & & 0.8 & 1.1 & 1.9 & & & 0.2 & 0.6 & 1.1 \\
\hline China & & 4.1 & 2.4 & & & & & & & \\
\hline Fiji & & 4.6 & 5.0 & & 5.1 & & 2.0 & 2.3 & & 2.8 \\
\hline Indonesia & & 1.0 & 0.8 & 1.2 & & & 0.3 & 0.4 & 0.5 & \\
\hline Korea, Rep. & & 2.9 & 2.6 & 2.3 & 2.7 & & & & & \\
\hline Lao PDR & & 0.7 & 0.2 & 1.4 & 1.4 & & 0.3 & 0.1 & 1.0 & 0.4 \\
\hline Malaysia & & 5.7 & 5.1 & 5.1 & 7.1 & & 1.4 & 1.4 & 1.5 & 2.0 \\
\hline Maldives & & 2.2 & 5.3 & 7.1 & 8.9 & & 1.5 & 2.7 & 4.3 & 4.8 \\
\hline Mongolia & & & 5.6 & 6.6 & 8.0 & & & 3.8 & 4.3 & 3.8 \\
\hline Nepal & & 2.0 & 2.3 & 2.5 & 3.0 & & 0.8 & 0.6 & 0.9 & 0.9 \\
\hline Papua New Guinea & & 5.8 & 5.3 & 5.0 & & & 2.9 & 2.4 & 1.6 & \\
\hline Philippines & & 2.8 & 2.8 & 3.7 & 3.0 & & 0.7 & 0.6 & 0.5 & 0.3 \\
\hline Sri Lanka & & 2.9 & 2.9 & 2.9 & 2.4 & & 1.7 & 1.5 & 1.6 & 1.8 \\
\hline Thailand & & & 4.5 & 4.4 & 4.0 & & & 1.5 & 1.4 & 1.4 \\
\hline East Asia \& Pacific & & 3.0 & & 2.0 & 3.0 & & & & 2.0 & 2.0 \\
\hline South Asia & & 3.0 & & 3.0 & & & & & 1.0 & 1.0 \\
\hline $\begin{array}{l}\text { Latin America \& } \\
\text { Caribbean }\end{array}$ & & 3.0 & & 4.0 & 4.0 & & & & 3.3 & 3.0 \\
\hline $\begin{array}{l}\text { Middle East \& North } \\
\text { Africa }\end{array}$ & & & & & & & & & 2.5 & 2.7 \\
\hline Sub-Saharan Africa & & 3.0 & & 3.0 & & & & & 3.0 & 3.0 \\
\hline Low income & & & & 5.2 & 5.5 & & & & 6.0 & $6.4^{*}$ \\
\hline Middle income & & & & 2.9 & & & & & 1.4 & $1.4^{*}$ \\
\hline High income & & & & 4.2 & 4.2 & & & & 2.9 & $2.9 *$ \\
\hline
\end{tabular}

Source: ADB key Indicators 2005 and WDI 2005

Note: *: Excluding 2004

In the case of education except for Fiji, Maldives, Malaysia, Papua New Guinea and Thailand, none of the Asia Pacific countries have expenditure levels close to the world average of 4 per cent of GDP. South Asia's public expenditure on education is only 3 per cent of GDP. China's expenditure was high during 1981-85 but has fallen off in more recent times.

The health expenditure figures are even worse. Whereas the world average expenditure on health was 5 per cent in 1996-2000 and 6 per cent during 2001-04 and the OECD figure was even higher at 6 per cent and 6.5 per cent respectively, the South Asian magnitude was a mere 1 per cent for both these periods, even lower than those of sub-Saharan Africa. Only Maldives had figures comparable to the world average. None of the major countries did. 
To better understand the expenditure dilemma facing these countries it is instructive to compare the expenditures on education and health with that on debt servicing (Table $15)$.

Table 15: Total Debt Service as Per Cent of GNI

\begin{tabular}{|c|c|c|c|c|c|}
\hline Countries/Regions & $\begin{array}{l}\text { Average } \\
1981-85\end{array}$ & $\begin{array}{l}\text { Average } \\
1986-90\end{array}$ & $\begin{array}{l}\text { Average } \\
1991-95\end{array}$ & $\begin{array}{l}\text { Average } \\
1996-00\end{array}$ & $\begin{array}{l}\text { Average } \\
\text { 2001-03 }\end{array}$ \\
\hline Bangladesh & 1.26 & 2.09 & 1.76 & 1.55 & 1.36 \\
\hline Bhutan & 0.00 & 1.06 & 3.16 & 2.08 & 1.24 \\
\hline Cambodia & & 0.95 & 0.67 & 0.56 & 0.60 \\
\hline China & 0.97 & 1.51 & 2.17 & 2.26 & 2.39 \\
\hline Fiji & 4.05 & 6.32 & 5.34 & 1.99 & 1.55 \\
\hline India & 1.23 & 2.27 & 3.32 & 2.76 & 2.66 \\
\hline Indonesia & 5.13 & 9.41 & 9.29 & 13.03 & 10.25 \\
\hline $\begin{array}{l}\text { Iran, Islamic Rep. } \\
\text { Korea, Rep. }\end{array}$ & \multicolumn{3}{|c|}{ Korea, Rep. } & 4.77 & 1.18 \\
\hline Lao PDR & 0.34 & 1.35 & 1.32 & 2.14 & 2.52 \\
\hline Malaysia & 8.72 & 13.68 & 7.41 & 7.89 & 8.74 \\
\hline Maldives & 9.03 & 6.47 & 3.01 & 3.66 & 3.50 \\
\hline \multicolumn{6}{|l|}{ Myanmar } \\
\hline Nepal & 0.73 & 1.47 & 1.88 & 1.90 & 1.81 \\
\hline Pakistan & 3.56 & 4.75 & 5.08 & 4.85 & 4.07 \\
\hline Papua New Guinea & 12.19 & 14.39 & 16.01 & 8.84 & 9.94 \\
\hline Philippines & 8.90 & 9.08 & 7.69 & 7.08 & 12.25 \\
\hline Samoa & 5.67 & 5.72 & 3.06 & 2.55 & 3.78 \\
\hline Sri Lanka & 5.04 & 6.36 & 4.11 & 4.11 & 4.20 \\
\hline Thailand & 6.28 & 7.05 & 5.28 & 10.09 & 14.81 \\
\hline Vietnam & & 3.29 & 2.24 & 3.69 & 3.08 \\
\hline East Asia \& Pacific & 3.45 & 4.75 & 4.57 & 4.67 & 4.79 \\
\hline South Asia & 1.59 & 2.60 & 3.42 & 2.93 & 2.75 \\
\hline Latin America \& Caribbean & 7.55 & 5.95 & 4.29 & 7.57 & 8.45 \\
\hline Middle East \& North Africa & 3.39 & 4.39 & 6.06 & 4.40 & 3.96 \\
\hline Sub-Saharan Africa & 8.64 & & 4.66 & 4.61 & 3.93 \\
\hline Europe \& Central Asia & 7.45 & 8.79 & 2.71 & 6.06 & 9.21 \\
\hline $\begin{array}{l}\text { Least developed } \\
\text { countries (UN classification) }\end{array}$ & 2.99 & 3.42 & 3.17 & 3.09 & 2.68 \\
\hline Low income & 3.18 & 3.69 & 4.17 & 3.56 & 3.11 \\
\hline Middle income & 5.29 & 5.32 & 4.19 & 5.98 & 6.88 \\
\hline High income & & & & & \\
\hline
\end{tabular}

Source: Computed from WDI (2005)

Figures from the two tables are not strictly comparable (since debt service is noted as a percentage of GNI and public expenditure on education and health as a percentage of GDP). Nevertheless, an indication of the differences in public expenditure magnitudes in the two broad cases can be gleaned from these two tables. China, which is well on its way to attaining MDG1 has lower debt servicing than public expenditure on education or health. For Indonesia, Lao, Malaysia, Maldives, Papua New Guinea, Philippines, Sri Lanka and Thailand debt servicing is higher than public expenditure on education and health. In several of these cases debt servicing is higher than the expenditure on education and health put together. Debt servicing obligations have increased over time in Indonesia, Lao, Nepal, Philippines, Thailand and Vietnam. On the other hand, very 
few countries in the Asia Pacific region have shown rising trends in expenditures on education and health. These include Maldives, Malaysia and Mongolia, (for education only). Expenditure levels for education and health in many countries have been stagnant or declining. This does not augur well for attaining the MDGs in respect of literacy and health unless resources are significantly augmented.

It stands to reason that any expansion of investible resources through the public sector, under such public revenue and public expenditure conditions, could lead to higher budgetary deficits. Some of these deficits could be monetized and/or spill over onto the current account. Hence any expansion of investible resources through the public sector should be accompanied with prudent macroeconomic management. Further such macroeconomic management should be accompanied by policy reforms at the micro level which encourage greater efficiency and, hence, lesser tendency toward excessive budgetary deficits.

\section{Measures to Augment Resources to Attain MDGs in Developing Countries}

We discuss tax reforms, expenditure switch policies, measures to boost FDI and to increase foreign aid.

\section{(i) Tax reform in Developing Countries}

The agenda for tax reform in developing countries has been widely discussed in the literature; see for instance Shome (1995) and World Bank (1991). Tax reforms are needed for increasing the tax/GDP ratio, limiting distortions in order to reduce some impediments to rapid economic growth and lowering disincentives to save, work, take risks and invest. Fine-tuning the tax structure to make it progressive should be looked upon as a component of an overall program of tax reform. It is widely agreed that existing patterns of taxation in developing countries are not only insufficiently progressive but also create distortions reducing potential economic growth, thereby stifling already scarce funds for poverty alleviation. The primary purpose of tax collection has to be the generation of sufficient revenues. However, in the case of many developing countries there appears to be a permanent gap between public expenditure and tax revenue with most tax revenues being collected from distortionary and regressive taxation such as excise and import tariffs. Income taxes have small bases and are, in most cases, subject to considerable evasion. Partly as a result of this, direct taxes get skewed in favour of corporate taxation. In many developing countries corporate income is taxed at more than one rate and the highest corporate tax rate is higher than the highest income tax rate. This creates an avenue for inter-tax arbitrage as well as evasion. High and arbitrary import tariffs have unintended consequences for effective rates of protection and industrial growth. One of the most regressive and distortionary taxes is the inflation tax, which countries in crisis routinely face during phases of high inflation. Further, tax structures in developing countries are unnecessarily complex with a multiplicity of taxes, rates and exemptions. Tax administration becomes difficult, as a consequence.

The literature has evolved fairly broad consensus on the direction of reforms for developing countries. The emphasis of the tax structure on direct taxation should increase. The income tax base should be enlarged and the number of rates brought 
down with substantial cuts in the top marginal rates. There should be a flat corporation tax rate and this rate should be harmonized with the highest income tax rate. The use of the tax system for special tax preferences should be scrutinized since using the system to provide tax incentives usually causes a serious drain on the national exchequer by conferring windfall gains on existing activities or by shifting resources to tax-preferred activities. A uniform broad-based consumption tax (such as a VAT) with few exemptions (for goods and services consumed in disproportionately large amounts by the poor), and few rates has been advocated. These could be supplemented with excise duties on environmental bads or 'luxuries'. ${ }^{6}$ Peak tariff duties and the dispersion of tariff rates are to be brought down gradually. Such tax reforms have the potential of improving the allocation of resources and enhance prospects for economic growth. They are also administratively simpler. If the tax base admits few exemptions and there are fewer rates, costs of compliance and monitoring are probably lower. A significant exception to this is the VAT, which requires fairly sophisticated account keeping in order to net out input costs and exempt exports. Such expertise may be lacking in many developing countries. The credibility of the tax regime is also important and tax reforms should aim for a stable tax environment. Further, tax reform should be well coordinated and across the board changes may necessitate policy reversals. A tariff cut, for example, should be accompanied by an upward revision of VAT rates, failing which there may be a drop in revenue.

While many authors have commended the shift to direct taxes, on the structure of the indirect taxes - particularly the use of the VAT - there is less room for optimism. Emran and Stiglitz (2003a, 2003b) show that the standard prescription of reducing trade taxes with an upward revision of the rate of a broad-based VAT (so as to keep revenue unchanged) is welfare improving only in an economy with no informal sector and all production and exchange activity in the tax net. These conditions are typically not satisfied in developing countries. CSO (2000) notes, for instance, that in 1999-00 as much as 60 percent of India's GDP came from the unorganized sector even as this sector provided employment to a staggering 92 percent of the labour force! When only the formal sector can be taxed and the informal can't, the introduction of a VAT (or a hike in its rate), far from removing distortions across goods and services, ends up creating a distortion between the formal and the informal sectors and may lead to lower welfare under plausible conditions. In such circumstances even broadening the VAT base to include more of the informal sector may reduce welfare. Whereas Piggott and Whalley (2001) simulate the welfare effects of introducing a VAT in the presence of an informal sector and show that welfare could decline under plausible conditions, formal econometric evidence on the effects of these reforms on tax revenue is relatively scant. Some of it is discussed below.

How successful have these tax reforms been in raising revenue? Given the high tax buoyancy in many developing countries (Jha 2006) one would expect that tax reforms that raise the rate of growth of the economy will in general, lead to substantial incremental revenues. The response of tax revenues to changes in the tax base is called tax buoyancy which is defined as:

$\theta=\frac{\text { Percentage change in tax revenue }}{\text { Percentage change in tax base }}$

${ }^{6}$ In federal countries there is the further issue of how to harmonize VAT across states. 
Table 16 indicates that tax buoyancy is high and averages over 1 in many developing countries.

Table 16: Tax Buoyancy in Select Low-Income Countries over 1975 to 1998

\begin{tabular}{llllll}
\hline Country & $\varepsilon$ & Country & $\varepsilon$ & Country & $\varepsilon$ \\
\hline Bangladesh & 2.26 & Guinea-Bissau & 0.43 & Nigeria & 0.15 \\
Bhutan & 1.61 & Haiti & 0.94 & Pakistan & 1.16 \\
Burkina Faso & 1.08 & India & 0.95 & Rwanda & 1.20 \\
Burundi & 1.46 & Indonesia & 0.99 & Senegal & 1.25 \\
Cameroon & 0.69 & Kenya & 1.45 & Sierra Leone & 0.73 \\
Chad & 0.48 & Lesotho & 1.95 & Solomon Islands & 1.38 \\
Comoros & 0.33 & Liberia & 1.22 & Togo & 0.91 \\
Congo, Dem. Rep. & 0.52 & Madagascar & 0.56 & Uganda & 0.72 \\
Congo, Rep. & 0.23 & Malawi & 1.48 & Vietnam & 0.67 \\
Cote d'Ivoire & 0.98 & Mali & 1.47 & Yemen, rep. & 1.45 \\
Ethiopia & 0.18 & Mauritania & 1.07 & Zambia & 0.59 \\
Gambia & 1.55 & Myanmar & 0.55 & Zimbabwe & 1.612 \\
Ghana & 0.96 & Nepal & 1.76 & Unweighted & 1.045 \\
Guinea & 0.82 & Nicaragua & 1.99 & Average & \\
\hline
\end{tabular}

Source: Teera (2002)

Thus, economic growth should lead to higher tax revenues in many of these developing countries.

Empirical evidence to support the claim that the introduction of VAT will lead to a rise in revenue is conflicting. Munoz and Cho (2003) study the impact of introducing a comprehensive VAT in Ethiopia and argue that the tax has not had an adverse impact on the poor and is progressive in its incidence. Further, the introduction of the VAT has been associated with a substantial increase in public sector revenue over the medium term, but not in the short run. However, even this result is suspect in view of the work of Ebrill et al. (2001) who find that the introduction of the VAT has led to a drop in tax revenues.

It should be remembered that VAT is only a recent tax reform instituted in many OECD countries and is now increasingly being adopted by developing countries. But there are problems associated with the use of VAT in developing countries. The administration of VAT is quite demanding for both taxpayers and authorities. This complexity would strengthen the case for a single rate VAT, however, many developing countries would want to build in some progression into the VAT structure. Another reason why developing countries find it difficult to switch to a VAT is because of their heavy reliance on sales taxes. These difficulties partly explain why VAT revenues have not gone up as fast as anticipated in many developing countries that have implemented these.

An interesting question to pose at this juncture is whether recent elements of tax reform in developed countries hold promise for developing countries. Heady (2002) considers this question and characterises recent reforms in taxation in OECD countries as 
consisting of the following elements: (i) reduction of personal and corporate income tax rates, accompanied by substantial base-broadening; (ii) simplification of tax rate structures; (iii) an increase in social security contributions; and (iv) a switch from traditional sales and excise taxes towards VAT, followed by an increase in VAT rates. As a consequence of these changes the shares of personal income taxes and excise duties in total revenue have fallen and those of corporate taxes, social security contributions and VAT risen.

Apart from the problems with the implementation of VAT in developing countries the emphasis on income taxation is also difficult because of administrative difficulties (Heady 2002). However, what can be pursued quite effectively in developing countries is the lowering of rates and expansion of base. This will encounter political opposition in these countries but probably less so than some other tax reforms, particularly if these changes are spaced out over time. The narrow tax bases and extensive tax evasion in many developing countries would argue in favour of such a policy. The policy of increasing social security contributions also has its appeal (Heady 2002) for two reasons. First, such a policy has the political advantage of earmarking a tax to pay for something the population would generally approve. Second, since social security contributions are applied almost exclusively to employment income and do not vary with the personal circumstances of the employee these are likely to be easier to administer than income taxes. However, these contributions have very little redistributive impacts and, by raising the cost of employing, can increase unemployment. ${ }^{7}$

Differences in the tax structures of developed and developing countries can be assessed through a comparison of tables 17, 18 and 19.

Table 17: Tax Structures in the OECD Countries (Percentage Share of Major Tax Categories in Total Tax Revenue)

\begin{tabular}{lrrrrr}
\hline Type of tax & 1965 & 1975 & 1985 & 1995 & 2000 \\
\hline Personal Income Tax & 26 & 30 & 30 & 27 & 26 \\
Corporate Income Tax & 9 & 8 & 8 & 8 & 10 \\
Social Security Contributions, of which & 18 & 22 & 22 & 25 & 25 \\
(employee) & 6 & 7 & 7 & 8 & 8 \\
(employer) & 10 & 14 & 13 & 14 & 15 \\
Payroll Taxes & 1 & 1 & 1 & 1 & 1 \\
Property Taxes & 8 & 6 & 5 & 5 & 5 \\
General Consumption Taxes & 12 & 13 & 16 & 18 & 18 \\
Specific Consumption Taxes & 24 & 18 & 16 & 13 & 12 \\
Other Taxes (including certain taxes on goods & 2 & 2 & 2 & 3 & 3 \\
and services and stamp taxes). & 100 & 100 & 100 & 100 & 100 \\
Total & & & & & \\
\hline
\end{tabular}

Source: Heady (2002)

In the Asia Pacific region most developing countries derive a smaller proportion of their total revenues from direct taxes than do OECD countries. Whereas OECD

\footnotetext{
7 Piecemeal and inappropriately sequenced tax reforms can sometimes have adverse consequences for tax revenue. Thus Chu et al. (2004) show that such tax reforms reduced the average tax/GDP ratio for a sample of 34 developing countries over 1975-95 (roughly) by about 1 percent of GDP whereas it rose by about 1.5 percent of GDP over the previous twenty years. Further, the share of direct taxes in total tax revenue also fell.
} 
countries derived 32 per cent of their tax revenues from income taxes in 1999 the figure was only 25 percent for India, 23 per cent for Pakistan, 7 per cent for Mongolia, and 17 per cent each for Myanmar and Nepal. Furthermore, while social security taxes amounted for 22 per cent of tax revenues in OECD countries these are virtually nonexistent in the Asia Pacific region. In the Asia Pacific region there seems to be a much greater reliance on sales taxes as well as trace taxes.

Table 18: Composition of Tax Revenue (\%)

\begin{tabular}{|c|c|c|c|c|c|c|}
\hline \multirow[t]{2}{*}{ Country } & \multicolumn{2}{|c|}{$\begin{array}{c}\text { Income } \\
\text { Taxes }\end{array}$} & \multicolumn{2}{|c|}{$\begin{array}{c}\text { Goods and } \\
\text { Services Taxes }\end{array}$} & \multicolumn{2}{|c|}{$\begin{array}{l}\text { International } \\
\text { Trade Taxes }\end{array}$} \\
\hline & $1990-94$ & $99-2003$ & $1990-94$ & $99-2003$ & $1990-94$ & $99-2003$ \\
\hline Bangladesh & 19.38 & 19.05 & 18.60 & 27.37 & 65.12 & 53.58 \\
\hline Bhutan & 29.35 & 55.45 & 64.95 & 37.38 & 3.18 & 4.42 \\
\hline India & 23.93 & 36.25 & 43.54 & 40.54 & 31.89 & 23.01 \\
\hline Maldives & 2.79 & 4.68 & 31.95 & 30.74 & 64.17 & 63.32 \\
\hline Nepal & 10.76 & 19.85 & 47.56 & 42.44 & 35.27 & 32.78 \\
\hline Pakistan & 17.75 & 28.51 & 38.99 & 44.01 & 38.76 & 14.38 \\
\hline Sri Lanka & 14.33 & 16.46 & 53.92 & 65.74 & 27.07 & 14.22 \\
\hline South Asia & 16.90 & 25.75 & 42.79 & 41.17 & 37.92 & 29.39 \\
\hline Cambodia & & 11.60 & & 51.44 & & 37.02 \\
\hline China & 44.23 & 9.49 & 33.33 & 75.52 & 22.27 & 10.52 \\
\hline Indonesia & 60.46 & 57.71 & 30.54 & 35.98 & 6.26 & 3.91 \\
\hline Korea, Rep. & 39.10 & 36.21 & 41.46 & 43.69 & 9.60 & 6.21 \\
\hline Lao PDR & & 23.11 & & 39.00 & & 15.63 \\
\hline Malaysia & 45.43 & 60.78 & 28.75 & 30.54 & 21.04 & 8.88 \\
\hline Mongolia & & 28.21 & & 61.89 & & 9.89 \\
\hline Myanmar & 26.94 & 36.36 & 49.23 & 56.46 & 23.83 & 7.18 \\
\hline Philippines & 33.16 & 44.66 & 31.37 & 30.49 & 31.42 & 19.97 \\
\hline Singapore & 44.77 & 50.50 & 27.88 & 30.97 & 3.05 & 2.70 \\
\hline Thailand & & 36.36 & & 50.71 & & 12.32 \\
\hline Vietnam & 21.68 & 30.72 & 33.28 & 41.25 & 30.64 & 21.73 \\
\hline East Asia & 39.47 & 35.47 & 34.48 & 45.66 & 18.51 & 13.00 \\
\hline Fiji & 39.63 & & 28.02 & & 30.53 & \\
\hline Papua New Guinea & 52.34 & 54.48 & 13.86 & 13.10 & 31.01 & 29.18 \\
\hline \multicolumn{7}{|l|}{ Samoa } \\
\hline Vanuatu & 0.00 & 0.00 & 31.40 & 56.87 & 68.60 & 41.12 \\
\hline Pacific & 30.66 & 27.24 & 24.43 & 34.98 & 43.38 & 35.15 \\
\hline Asia and the Pacific & 29.22 & 31.45 & 36.03 & 43.15 & 30.21 & 20.57 \\
\hline Latin America \& Caribbean & 27.52 & 26.04 & 42.86 & 52.73 & 23.19 & 12.26 \\
\hline Sub Saharan Africa & 28.61 & 26.31 & 32.51 & 35.90 & 35.78 & 34.40 \\
\hline Middle East \& North Africa & 39.55 & 41.15 & 24.16 & 28.81 & 28.28 & 21.76 \\
\hline OECD & 58.25 & 49.71 & 32.95 & 44.44 & 3.61 & 0.75 \\
\hline DevelopingCountries & 30.43 & 30.45 & 34.27 & 40.82 & 30.25 & 22.85 \\
\hline World & 31.78 & 35.39 & 34.21 & 41.75 & 28.96 & 17.19 \\
\hline Low income & 25.89 & 27.69 & 36.56 & 40.73 & 33.92 & 27.84 \\
\hline Middle income & 33.43 & 31.98 & 32.73 & 41.18 & 28.29 & 19.62 \\
\hline High income & 54.88 & 49.75 & 31.68 & 43.82 & 3.47 & 0.84 \\
\hline
\end{tabular}

Source: ADB (2005) Key Indicators and World Bank (2005). 
Resource Augmentation for Meeting the MDGs in the Asia-Pacific Region

Table 19: Tax Mix of Selected Low-Income Countries and Groups of Countries (1999)

\begin{tabular}{|c|c|c|c|c|}
\hline $\begin{array}{l}\text { Selected Low Income } \\
\text { Countries }\end{array}$ & $\begin{array}{c}\text { Income Taxes } \\
\text { as } \% \text { of } \\
\text { Revenue }\end{array}$ & $\begin{array}{c}\text { Social Security } \\
\text { Taxes as \% of } \\
\text { Revenue }\end{array}$ & $\begin{array}{l}\text { Sales Taxes as \% } \\
\text { of Revenue }\end{array}$ & $\begin{array}{l}\text { Trade Taxes as \% } \\
\text { of Revenue }\end{array}$ \\
\hline Azerbaijan & 22 & 22 & 40 & 9 \\
\hline Bangladesh & 11 & 0 & 40 & 23 \\
\hline Bhutan & 20 & 0 & 13 & 2 \\
\hline Burundi & 21 & 7 & 44 & 20 \\
\hline Cameroon & 21 & 0 & 26 & 28 \\
\hline Congo, Republic & 8 & 0 & 15 & 6 \\
\hline Cote d'Ivoire & 22 & 6 & 18 & 47 \\
\hline Georgia & 10 & 17 & 55 & 4 \\
\hline Guinea & 10 & 1 & 5 & 77 \\
\hline India & 25 & 0 & 28 & 21 \\
\hline Indonesia & 59 & 2 & 28 & 3 \\
\hline Kyrgyz Republic & 15 & 0 & 58 & 4 \\
\hline Madagascar & 15 & 0 & 25 & 56 \\
\hline Moldova & 5 & 26 & 50 & 8 \\
\hline Mongolia & 7 & 20 & 41 & 5 \\
\hline Myanmar & 17 & 0 & 35 & 27 \\
\hline Nepal & 17 & 0 & 35 & 29 \\
\hline Nicaragua & 12 & 13 & 58 & 7 \\
\hline Pakistan & 23 & 0 & 29 & 14 \\
\hline Sierra Leone & 26 & 0 & 22 & 49 \\
\hline Sudan & 15 & 0 & 35 & 29 \\
\hline Tajkistan & 7 & 17 & 59 & 13 \\
\hline Uganda & 16 & 0 & 64 & 10 \\
\hline Ukraine & 11 & 39 & 37 & 4 \\
\hline Vietnam & 22 & 0 & 35 & 20 \\
\hline Yemen, Republic & 16 & 0 & 9 & 10 \\
\hline \multicolumn{5}{|l|}{ Group Averages } \\
\hline Lower-middle income Countries & 18 & 4 & 36 & 10 \\
\hline Upper-middle income countries & 19 & 21 & 38 & 4 \\
\hline Non-OECD high income & 13 & 6 & 31 & 1 \\
\hline OECD & 32 & 22 & 28 & 0 \\
\hline
\end{tabular}

N.B. Rows do not add to 100 because of other taxes and non-tax revenues.

Source: Heady (2002) and Palanivel (2006) 


\section{(ii) Inadequate expenditure policies}

Jha (2006) models the determinants of expenditure/GDP ratio $^{8}$ in 13 developing countries (Asia pacific countries included were India, Indonesia, Malaysia, Sri Lanka and Thailand) over the period 1985-2002. Results of a panel fixed effects regression of In (exp/GDP) against In (per capita real income) and a time trend using annual data for the period 1980-98 are as:

$$
\begin{aligned}
\ln (\exp / \mathrm{GDP}) & =3.55-0.00635 * \text { time trend }-0.05965 * \ln (\mathrm{pc} \text { real income }) \\
(6.504) & (-2.888)
\end{aligned}
$$

t-statistics are in parentheses below the respective coefficients. The time trend and the constant are strongly significant. The coefficient on per capita real income is insignificant. The F-statistic is strongly significant. Thus, if anything, public expenditure in developing countries is on a downward trend. With growth of per capita income tax/GDP ratios tend to increase whereas there is no significant change in the expenditure/GDP ratio. Over time both tax/GDP and expenditure/GDP ratios fall. Thus in many developing countries the essential problem is not that of pruning public expenditure but of switching public expenditure towards programs that directly impact upon the MDG, e.g., public expenditure on education and health (Table 14).

Over the medium term, as globalization proceeds demands for public expenditure are likely to rise (Rodrik 1998).

\section{(iii) Foreign Direct Investment}

We have already commented on the optimistic outlook with regard to FDI for many developing counties of the Asia Pacific region. Table 20 notes the development of FDI inflows as percentage of gross capital formation in several Asia Pacific countries as well as some regions.

As Table 20 indicates for most developing countries of the Asia Pacific foreign direct investment forms only a small proportion of total capital formation, rarely above 5 per cent. Major exceptions are China, Fiji (for some of the period), Lao, Malaysia, Maldives, Mongolia, Papua New Guinea, Thailand and Vietnam. .Some countries (e.g. Indonesia) have experienced negative growth of FDI. The contribution of FDI to investment in South Asia during 2001-04 was only 3.4 per cent compared to 11.0 per cent for the world as a whole and 10.5 per cent for the high income OECD countries. .

\footnotetext{
${ }^{8}$ Public expenditure in developing countries - even those with low tax/GDP ratios - has not been excessive, especially when compared with public expenditure in OECD countries. If one nets out debt servicing charges expenditure/GDP ratios are likely to be even lower.
} 
Resource Augmentation for Meeting the MDGs in the Asia-Pacific Region

Table 20: Net FDI Inflows as Percentage of Gross Capital Formation: 1981-2004 (\% per annum)

\begin{tabular}{lccccc}
\hline Countries/Regions & $1981-1985$ & $1986-1990$ & $1991-1995$ & $1996-2000$ & $2001-2004$ \\
\hline Bangladesh & -0.0 & 0.0 & 0.1 & 1.6 & $1.1^{*}$ \\
Bhutan & 0.0 & 0.0 & 0.2 & 0.1 & 0.3 \\
Cambodia & & & & 40.4 & $14.0^{\star}$ \\
China & 0.8 & 1.8 & 9.1 & 10.9 & $8.3^{\star}$ \\
Fiji & 9.6 & 9.3 & 24.6 & -5.6 & \\
India & 0.0 & 0.0 & 0.9 & 2.8 & $3.1^{\star}$ \\
Indonesia & 0.9 & 2.0 & 3.9 & -2.3 & -3.9 \\
Iran, Islamic Rep. & 0.0 & 0.0 & 0.0 & 0.1 & \\
Korea, Rep. & -0.2 & -0.2 & -0.6 & 1.1 & $0.1^{\star}$ \\
Lao PDR & 0.0 & 0.8 & 20.7 & 19.3 & 6.4 \\
Malaysia & 11.8 & 10.8 & 18.0 & 11.2 & $4.0^{\star}$ \\
Maldives & & & 5.7 & 6.9 & 7.1 \\
Mongolia & & & 3.7 & 8.6 & 16.7 \\
Nepal & 0.0 & 0.0 & 0.0 & 0.9 & \\
Pakistan & 1.4 & 2.2 & 4.0 & 5.1 & 4.9 \\
Papua New Guinea & 15.0 & 19.1 & 15.6 & 20.3 & \\
Philippines & 0.6 & 6.4 & 5.8 & 9.8 & $7.5^{\star}$ \\
Sri Lanka & 3.63 & 2.5 & 4.2 & 5.6 & \\
Thailand & 2.4 & 4.4 & 3.0 & 14.9 & 5.3 \\
Vietnam & & & & 23.3 & 12.4 \\
\hline East Asia \& Pacific & 1.94 & 3.40 & 9.39 & 11.03 & $8.51^{*}$ \\
South Asia & 0.2 & 0.2 & 1.3 & 3.0 & $3.4^{*}$ \\
Latin America \& Caribbean & 4.0 & 3.4 & 6.8 & 17.4 & $14.3^{\star}$ \\
Middle East \& North Africa & & & & & \\
Sub-Saharan Africa & 2.0 & 3.0 & 5.2 & 11.6 & $16.6^{*}$ \\
Low income & 1.3 & 1.5 & 4.3 & 6.7 & $6.6^{*}$ \\
Middle income & 3.4 & 2.1 & 6.0 & 12.1 & $10 . *^{*}$ \\
High income & 2.1 & 4.0 & 3.4 & 12.4 & $11.1^{*}$ \\
\hline
\end{tabular}

Source: World Bank, WDI CD-ROM, 2003, and ADB key Indicators 2003

Note: *: Excluding 2004

Prospects for FDI in the near future appear fairly optimistic as Table 21 indicates. 


\section{R. Jha \& T. Palanivel}

Table 21: Summary of Survey Results

\begin{tabular}{|c|c|c|c|c|c|c|}
\hline & \multicolumn{3}{|l|}{ Global Prospects } & \multicolumn{3}{|c|}{ Regional Prospects } \\
\hline & & $\begin{array}{c}\text { Developed } \\
\text { Countries } \\
\end{array}$ & Africa & Asia \& the Pacific & $\begin{array}{c}\text { Latin American \& } \\
\text { the Caribbean }\end{array}$ & $\begin{array}{c}\text { Southeast Europe } \\
\text { \& CIS }\end{array}$ \\
\hline \multirow{4}{*}{$\begin{array}{l}\text { Prospects for } \\
\text { FDI Flows in } \\
2005-2006 \\
\text { (increase/ } \\
\text { remain the samel } \\
\text { decrease) }\end{array}$} & Experts & & & & & \\
\hline & $\begin{array}{l}59 \% / 41 \% / 0 \% \\
\text { IPAs }\end{array}$ & $30 \% / 55 \% / 15 \%$ & $37 \% / 49 \% / 14 \%$ & $85 \% / 13 \% / 2 \%$ & $41 \% / 48 \% / 11 \%$ & $86 \% / 12 \% / 12 \%$ \\
\hline & $\begin{array}{l}81 \% / 15 \% / 5 \% \\
\text { TNCs }\end{array}$ & $72 \% / 28 \% / 0 \%$ & $88 \% / 4 \% / 8 \%$ & $96 \% / 4 \% / 0 \%$ & $63 \% / 29 \% / 8 \%$ & $91 \% / 0 \% / 9 \%$ \\
\hline & $56 \% / 42 \% / 2 \%$ & $27 \% / 59 \% / 14 \%$ & $24 \% / 55 \% / 21 \%$ & $89 \% / 8 \% / 3 \%$ & $36 \% / 58 \% / 5 \%$ & $88 \% / 12 \% / 0 \%$ \\
\hline \multirow{5}{*}{$\begin{array}{l}\text { Most attractive } \\
\text { business location } \\
\text { (TNC responses) }\end{array}$} & 1. China & 1. U.S. & 1. South Africa & 1. China & 1. Brazil & 1. Russia \\
\hline & 2. India & 2. Canada & 2. Egypt & 2. India & 2. Mexico & 2. Romania \\
\hline & 3. U.S. & 3. U.K. & 3. Morocco & 3. Thailand & 3. Argentina & 3. Ukraine \\
\hline & 4. Russia & 4. Germany & 4. Nigeria & 4. S. Korea & 4. Chile & 4. Kazakhstan \\
\hline & 5. Brazil & 5. France & 5. Tunisia & 5. Malaysia & 5. Venezuela & 5. Croatia \\
\hline \multirow{3}{*}{$\begin{array}{l}\text { Expected Leading } \\
\text { sources of FDI } \\
\text { in 2005-2006 } \\
\text { (IPA responses) }\end{array}$} & 1. U.S. & 1. U.S. & 1. South Africa & 1. U.S. & 1. U.S. & 1. U.S. \\
\hline & 2. U.K. & 2. Germany & 2. China & 2. China & 2. Spain & 2. Netherlands \\
\hline & 3. Germany & 3. U.K. & 3. U.K. & 3. Japan & 3. Brazil & 3. U.K. \\
\hline \multirow{6}{*}{$\begin{array}{l}\text { Industries with } \\
\text { most positive } \\
\text { outlook for } \\
2005-2006 \\
\text { (IPA responses) }\end{array}$} & $\begin{array}{l}\text { Computing } \\
\text { \& ICT }\end{array}$ & $\begin{array}{l}\text { Computing } \\
\text { \& ICT }\end{array}$ & $\begin{array}{l}\text { Tourism, hotel } \\
\text { \& restaurants }\end{array}$ & Construction & $\begin{array}{l}\text { Tourism, hotel } \\
\text { \& restaurants }\end{array}$ & Construction \\
\hline & $\begin{array}{l}\text { Electricity, } \\
\text { gas \& water }\end{array}$ & $\begin{array}{l}\text { Tourism, hotel \& } \\
\text { restaurants }\end{array}$ & Computing \& ICT & $\begin{array}{l}\text { Computing } \\
\text { \& ICT }\end{array}$ & Construction & $\begin{array}{l}\text { Computing } \\
\quad \& I C T\end{array}$ \\
\hline & Transportation & Transportation & $\begin{array}{l}\text { Mining \& } \\
\text { Petroleum }\end{array}$ & $\begin{array}{l}\text { Tourism, hotel } \\
\& \text { restaurants }\end{array}$ & $\begin{array}{l}\text { Computing } \\
\quad \& \text { ICT }\end{array}$ & Food \& beverages \\
\hline & $\begin{array}{l}\text { Tourism, hotel } \\
\& \text { restaurants }\end{array}$ & $\begin{array}{l}\text { Electrical \& } \\
\text { electronic } \\
\text { products }\end{array}$ & Construction & $\begin{array}{l}\text { Business } \\
\text { Services }\end{array}$ & $\begin{array}{l}\text { Tourism, hotel } \\
\& \text { restaurants }\end{array}$ & Transport \\
\hline & $\begin{array}{l}\text { Electrical \& } \\
\text { electronic } \\
\text { products }\end{array}$ & Business Services & $\begin{array}{l}\text { Electrical \& } \\
\text { electronic } \\
\text { products }\end{array}$ & $\begin{array}{l}\text { Education } \\
\text { \& Health }\end{array}$ & $\begin{array}{l}\text { Electricity, } \\
\text { gas \& water }\end{array}$ & Chemicals \\
\hline & $\begin{array}{l}\text { Mining \& } \\
\text { Petroleum }\end{array}$ & $\begin{array}{c}\text { Retail \& } \\
\text { wholesale }\end{array}$ & $\begin{array}{l}\text { Electricity, } \\
\text { gas \& water }\end{array}$ & Metal & $\begin{array}{l}\text { Mining \& } \\
\text { Petroleum }\end{array}$ & $\begin{array}{l}\text { Electrical \& } \\
\text { electronic } \\
\text { products }\end{array}$ \\
\hline \multirow{2}{*}{$\begin{array}{l}\text { Corporate } \\
\text { functions } \\
\text { in 2005-2006 } \\
\text { (IPA responses) }\end{array}$} & $\begin{array}{l}\text { Production } \\
(84 \%)\end{array}$ & $R \& D(84 \%)$ & $\begin{array}{l}\text { Production } \\
(92 \%)\end{array}$ & $\begin{array}{l}\text { Production } \\
(91 \%)\end{array}$ & $\begin{array}{l}\text { Production } \\
(71 \%)\end{array}$ & $\begin{array}{l}\text { Production } \\
(100 \%)\end{array}$ \\
\hline & $\begin{array}{l}\text { Distribution \& } \\
\text { sales (64\%) }\end{array}$ & $\begin{array}{c}\text { Production, } \\
\text { logistic \& support } \\
\text { services (76\%) }\end{array}$ & $\begin{array}{l}\text { Distribution \& } \\
\text { sales }(79 \%)\end{array}$ & $\begin{array}{c}\text { Logistics \& } \\
\text { supporting } \\
\text { services }(87 \%)\end{array}$ & $\begin{array}{c}\text { Regional } \\
\text { headquarters, } \\
\text { logistics \& } \\
\text { services (50\%) }\end{array}$ & $\begin{array}{l}\text { Distribution \& } \\
\text { sales (64\%) }\end{array}$ \\
\hline $\begin{array}{l}\text { Expected modes } \\
\text { of FDI in } \\
2005-2006 \\
\text { (IPA responses) }\end{array}$ & $M \& A$ & $M \& A$ & Greenfield & Greenfield & Greenfield & Greenfield \\
\hline \multirow{3}{*}{$\begin{array}{l}\text { Plans for new } \\
\text { investment policy } \\
\text { measures in } \\
2005-2006 \\
\text { (IPA responses) }\end{array}$} & $\begin{array}{l}\text { 1. Greater } \\
\text { targeting }\end{array}$ & $\begin{array}{l}\text { 1. Greater } \\
\text { targeting }\end{array}$ & $\begin{array}{l}\text { 1. Greater } \\
\text { targeting }\end{array}$ & $\begin{array}{l}\text { 1. Greater } \\
\text { targeting }\end{array}$ & $\begin{array}{l}\text { 1. Greater } \\
\text { targeting }\end{array}$ & $\begin{array}{l}\text { 1. Greater } \\
\text { targeting }\end{array}$ \\
\hline & $\begin{array}{l}\text { 2. Other promo- } \\
\text { tion measures }\end{array}$ & $\begin{array}{l}\text { 2. Additional } \\
\text { incentives }\end{array}$ & $\begin{array}{l}\text { 2. Additional } \\
\text { incentives }\end{array}$ & $\begin{array}{l}\text { 2. Further } \\
\text { Liberalisation }\end{array}$ & $\begin{array}{l}\text { 2. Other promo- } \\
\text { tion measures }\end{array}$ & $\begin{array}{l}\text { 2. Additional } \\
\text { incentives }\end{array}$ \\
\hline & $\begin{array}{l}\text { 3. Additional } \\
\text { incentives }\end{array}$ & $\begin{array}{l}\text { 3. Further } \\
\text { Liberalisation }\end{array}$ & $\begin{array}{l}\text { 3. Further } \\
\text { Liberalisation }\end{array}$ & $\begin{array}{l}\text { 3. Additional } \\
\text { incentives }\end{array}$ & $\begin{array}{l}\text { 3. Additional } \\
\text { incentives }\end{array}$ & $\begin{array}{l}\text { 3. Further } \\
\text { Liberalisation }\end{array}$ \\
\hline \multirow{4}{*}{$\begin{array}{l}\text { Major threats to } \\
\text { global FDI flows } \\
\text { in } 2005-2006 \\
\text { (\% of total, } \\
\text { expert \& TNC } \\
\text { responses) }\end{array}$} & \multicolumn{2}{|c|}{ Experts } & \multicolumn{2}{|c|}{ IPAs } & \multicolumn{2}{|c|}{ TNCs } \\
\hline & \multicolumn{2}{|c|}{ 1. Protectionism (89\%) } & \multicolumn{2}{|c|}{$\begin{array}{l}\text { 1. Financial instability of major } \\
\text { economies }(92 \%)\end{array}$} & \multicolumn{2}{|c|}{ 1. Protectionism (100\%) } \\
\hline & \multicolumn{2}{|c|}{ 2. Global terrorism threat (81\%) } & \multicolumn{2}{|c|}{$\begin{array}{l}\text { 2. Price Volatility of petroleum \& } \\
\text { other raw materials ( } 81 \%)\end{array}$} & \multicolumn{2}{|c|}{$\begin{array}{l}\text { 2. Slow growth in industrialised } \\
\text { countries }(89 \%)\end{array}$} \\
\hline & \multicolumn{2}{|c|}{$\begin{array}{l}\text { 3. Slow growth in industrialised } \\
\text { countries }(80 \%)\end{array}$} & \multicolumn{2}{|c|}{$\begin{array}{l}\text { 3. Political instability \& civil wars } \\
(78 \%)\end{array}$} & \multicolumn{2}{|c|}{$\begin{array}{l}\text { 3. Financial instability of major } \\
\text { economies }(84 \%)\end{array}$} \\
\hline
\end{tabular}

Source: UNCTAD (2005) 
UN (2006) broadly indicates a sanguine picture for FDI in the near term with only a small fraction of respondents to the UN's Survey indicating that FDI could fall. Such optimism is facilitated by relatively stable macroeconomic outlooks for the major economies, sustained high corporate profits and liberalization of investment regimes in countries receiving FDI. Concurrently competition to attract FDI has gone up steadily.

The same survey indicated that the medium-term prospects (2007-08) appeared good as well with 57 per cent of experts, 65 per cent of TNC's and 83 per cent of IPA's expecting to actually increase. This belief is predicated on the assumed buoyancy in global economic growth and the observed empirical regularity that booms in FDI follow period of high economic growth. However, there is some reason to believe that the medium-term economic growth prospects may be less sanguine. Investment prospects in the OECD are expected to stagnate after 2006. Contributing to this are fifteen straight interest rate hikes in the US, and a northward moving interest rate outlook for Europe as well as Japan, rising petroleum and raw material prices and other geopolitical concerns. Factors counteracting such negative sentiment include anticipated high profits in OECD countries which have led to high indices for business confidence.

There is also ample evidence in the survey that investors seem to be moving away from traditional destinations in developed countries to rapidly transforming economies some of which, including China and India, are in the Asia Pacific region. Thus in 2005 whereas the US is the most important source of global FDI, followed by the UK, Germany and China the top 15 recipients in 2005 included China, South Africa, India, Brazil, Malaysia, and South Korea.

There is considerable evidence to suggest that global competition for FDI has become more pro-active. Apart from regulatory reforms tax reforms and harmonization are used as major policy tools to attract FDI. Further many recent free trade agreements (FTA) and economic partnership agreements (EPA) have made serious efforts to liberalize, protect and promote cross-border investment. By June 2005 as many as 215 FTS or EPAs with investment components had been completed. Most of them seek to enhance FDI flows. Even preferential trade agreements have inducements for traderelated or "barrier-hopping" investment.

Hence, both national policies as well as international agreements are geared towards enhancing FDI at the same time as competition for FDI is goring in most countries. While these augur well for future FDI flows there may yet be a temporary slackness in FDI flows over 2007-08 due to the interest rate hikes, inflationary fears and the emerging geopolitical situation.

\section{(iv) International Aid}

Another possible source of investible resources is international aid. In Table 22 we depict aid disbursements to developing countries as a proportion of national income and in Table 23 as a proportion of capital formation in these countries. 
R. Jha \& T. Palanivel

Table 22: Aid as Percent of Gross National Income

\begin{tabular}{|c|c|c|c|c|c|}
\hline Countries/Regions & $\begin{array}{l}\text { Average } \\
1981-85\end{array}$ & $\begin{array}{l}\text { Average } \\
1986-90\end{array}$ & $\begin{array}{l}\text { Average } \\
1991-95\end{array}$ & $\begin{array}{l}\text { Average } \\
1996-00\end{array}$ & $\begin{array}{l}\text { Average } \\
\text { 2001-03 }\end{array}$ \\
\hline Bangladesh & 5.94 & 6.57 & 4.78 & 2.55 & 2.17 \\
\hline Bhutan & 10.80 & 16.56 & 27.88 & 17.01 & 13.18 \\
\hline Cambodia & & & 11.44 & 10.71 & 12.33 \\
\hline China & 0.28 & 0.50 & 0.61 & 0.25 & 0.11 \\
\hline Fiji & 3.02 & 3.51 & 3.23 & 2.06 & 2.08 \\
\hline India & 0.86 & 0.68 & 0.76 & 0.39 & 0.27 \\
\hline Indonesia & 0.90 & 1.49 & 1.22 & 1.02 & 0.91 \\
\hline Iran, Islamic Rep. & 0.01 & 0.05 & 0.21 & 0.16 & 0.10 \\
\hline Korea, Rep. & 0.10 & 0.02 & 0.00 & -0.02 & -0.04 \\
\hline Lao PDR & 1.87 & 10.08 & 15.01 & 19.39 & 15.02 \\
\hline Malaysia & 0.70 & 0.74 & 0.27 & -0.03 & 0.08 \\
\hline Maldives & 8.13 & 13.67 & 13.02 & 5.30 & 3.81 \\
\hline \multicolumn{6}{|l|}{ Myanmar } \\
\hline Nepal & 8.16 & 11.37 & 10.98 & 7.82 & 7.20 \\
\hline Pakistan & 2.44 & 2.85 & 2.28 & 1.25 & 2.41 \\
\hline Papua New Guinea & 13.07 & 11.31 & 8.63 & 7.73 & 7.41 \\
\hline Philippines & 1.21 & 2.27 & 2.20 & 0.87 & 0.76 \\
\hline Samoa & 20.51 & 23.83 & 28.83 & 12.47 & 15.43 \\
\hline Singapore & 0.15 & 0.13 & 0.03 & 0.00 & 0.01 \\
\hline Sri Lanka & 8.43 & 8.61 & 6.57 & 2.39 & 2.62 \\
\hline Thailand & 1.13 & 1.00 & 0.56 & 0.59 & -0.07 \\
\hline Vietnam & & & 4.06 & 4.52 & 4.22 \\
\hline East Asia \& Pacific & 0.86 & 1.10 & 1.01 & 0.58 & 0.41 \\
\hline South Asia & 1.65 & 1.63 & 1.67 & 0.83 & 0.92 \\
\hline Latin America \& Caribbean & 0.41 & 0.50 & 0.42 & 0.31 & 0.33 \\
\hline Middle East \& North Africa & 1.29 & 1.34 & 1.61 & 0.89 & 0.88 \\
\hline Sub-Saharan Africa & 3.74 & 5.47 & 6.52 & 4.60 & 5.56 \\
\hline Europe \& Central Asia & & & 0.97 & 0.97 & 0.92 \\
\hline $\begin{array}{l}\text { Least developed countries } \\
\text { (UN classification) }\end{array}$ & 7.46 & 9.17 & 11.63 & 7.69 & \\
\hline Low income & 2.87 & 3.46 & 4.40 & 2.68 & 2.88 \\
\hline Middle income & 0.45 & 0.54 & 0.72 & 0.47 & 0.46 \\
\hline High income & 0.02 & 0.02 & 0.01 & 0.01 & 0.00 \\
\hline
\end{tabular}

Source: Computed from WDI (2005)

Small countries and/or those recovering from the effects of prolonged conflict such as Bhutan, Cambodia, Nepal, Papua New Guinea and Samoa have high aid/GNI ratios. Even among such countries this ratio has fallen for Fiji and the Maldives. For most countries this ratio seems to have dropped off over time or remained, more or less unchanged. .Thus while this ratio has fallen in South Asia it has remained relatively unchanged for low income countries. 
Table 23: Aid as Percent of Gross Capital Formation

\begin{tabular}{|c|c|c|c|c|c|}
\hline Countries/Regions & $\begin{array}{l}\text { Average } \\
1981-85\end{array}$ & $\begin{array}{l}\text { Average } \\
1986-90\end{array}$ & $\begin{array}{l}\text { Average } \\
1991-95\end{array}$ & $\begin{array}{l}\text { Average } \\
1996-00\end{array}$ & $\begin{array}{l}\text { Average } \\
2001-03\end{array}$ \\
\hline Bangladesh & 35.83 & 40.47 & 27.64 & 12.31 & 9.75 \\
\hline Bhutan & 21.35 & 42.02 & 58.75 & 37.01 & 22.29 \\
\hline Cambodia & & & 97.21 & 70.53 & 54.08 \\
\hline China & 0.83 & 1.38 & 1.56 & 0.64 & 0.28 \\
\hline Fiji & 12.87 & 22.08 & 21.91 & 16.37 & 10.97 \\
\hline India & 3.94 & 2.92 & 3.26 & 1.74 & 1.18 \\
\hline Indonesia & 3.08 & 4.72 & 3.63 & 6.17 & 5.29 \\
\hline Iran, Islamic Rep. & 0.04 & 0.21 & 0.93 & 0.64 & 0.26 \\
\hline Korea, Rep. & 0.32 & 0.07 & -0.01 & -0.08 & -0.13 \\
\hline Lao PDR & 28.63 & 53.16 & 67.31 & 77.21 & 72.20 \\
\hline Malaysia & 2.20 & 2.72 & 0.68 & 0.09 & 0.33 \\
\hline Maldives & & & 46.41 & 16.27 & 12.92 \\
\hline Nepal & 43.21 & 55.82 & 50.15 & 32.11 & 29.16 \\
\hline Pakistan & 14.17 & 15.97 & 11.74 & 7.05 & 13.81 \\
\hline Papua New Guinea & 46.76 & 46.31 & 36.38 & 37.94 & 46.25 \\
\hline Philippines & 5.34 & 11.62 & 10.07 & 4.22 & 4.14 \\
\hline \multicolumn{6}{|l|}{ Samoa } \\
\hline Singapore & 0.31 & 0.36 & 0.08 & 0.01 & 0.03 \\
\hline Sri Lanka & 31.03 & 36.47 & 26.23 & 9.27 & 11.76 \\
\hline Thailand & 3.89 & 3.19 & 1.34 & 2.39 & -0.24 \\
\hline Vietnam & & & 18.68 & 15.57 & 12.69 \\
\hline East Asia \& Pacific & 2.67 & 3.28 & 2.72 & 1.70 & 1.14 \\
\hline South Asia & 7.86 & 7.34 & 7.46 & 3.80 & 4.16 \\
\hline Latin America \& Caribbean & 1.95 & 2.35 & 1.98 & 1.44 & 1.68 \\
\hline Middle East \& North Africa & 5.20 & 6.01 & 7.04 & 4.11 & 3.75 \\
\hline Sub-Saharan Africa & 19.36 & 29.84 & 35.56 & 24.50 & 27.86 \\
\hline Europe \& Central Asia & & & 3.69 & 4.27 & 4.11 \\
\hline $\begin{array}{l}\text { Least developed countries } \\
\text { (UN classification) }\end{array}$ & 55.11 & 59.80 & 64.97 & 37.79 & \\
\hline Low income & 14.27 & 16.41 & 20.44 & 12.36 & 12.74 \\
\hline Middle income & 1.70 & 2.03 & 2.72 & 1.85 & 1.76 \\
\hline High income & 0.10 & 0.07 & 0.05 & 0.04 & 0.03 \\
\hline
\end{tabular}

Source: Computed from WDI (2005)

Of course, not all aid is geared towards capital formation. Even so, table 23 indicates that aid as a proportion of capital formation has been declining over time in most countries of the Asia pacific region as well as in country groups. Pakistan, Papua New Guinea and Sri Lanka appear to be the only exceptions.

These results, notwithstanding, total net flows have often been negative for developing countries as Tables 24 and 25 indicate. For developing and transition countries total net flows turned negative to $-\$ 34.7$ billion from $\$ 107.5$ billion the previous year. If one factors in changes in reserves financial flows have been negative for the past three years. For east and South Asia net financial flows have been positive, however, much of these results are driven by China and prosperous East Asian economies such as 
South Korea. In Africa total net flows are mildly positive but turn negative when reserve changes are included. Thus for developing countries as a group the net foreign inflow situation is not very optimistic.

If one adds to this less than sanguine picture of international aid inadequate progress in global trade liberalisation, we come to the conclusion that developing countries of the Asia Pacific region do not face a very supportive international environment for the attainment of MDG1.

Table 24: Net Transfer of Financial Resources to Developing Economies and Economies in Transition: 1995-2005 (billions of dollars)

\begin{tabular}{|c|c|c|c|c|c|c|c|c|c|c|c|}
\hline Regions & 1995 & 1996 & 1997 & 1998 & 1999 & 2000 & 2001 & 2002 & 2003 & 2004 & $2005^{a}$ \\
\hline $\begin{array}{l}\text { Developing } \\
\text { Economies }\end{array}$ & 38.9 & 16.2 & -8.1 & -40.7 & -129.3 & -192.4 & -163.6 & -215.6 & -302.1 & -374.0 & -483.4 \\
\hline Africa & 6.4 & -5.7 & -4.7 & 15.6 & 4.5 & -26.5 & -16.0 & -4.9 & -19.6 & -32.4 & -55.6 \\
\hline \multicolumn{12}{|l|}{ Of which } \\
\hline $\begin{array}{l}\text { Atrica (excluding } \\
\text { Nigeria and } \\
\text { South Africa) }\end{array}$ & 7.4 & 5.3 & 7.5 & 12.1 & 9.3 & 2.8 & 6.8 & 6.1 & 7.0 & 5.3 & 2.0 \\
\hline $\begin{array}{l}\text { Eastern and } \\
\text { Southern Asia }\end{array}$ & 22.1 & 18.5 & -31.1 & -128.3 & -142.2 & -124.3 & -118.3 & -149.1 & -173.0 & -184.8 & -189.1 \\
\hline Western Asia & 13.9 & 3.9 & 4.9 & 28.1 & -0.9 & -39.5 & -32.6 & -27.8 & -47.6 & -75.6 & -154.6 \\
\hline Latin America & -3.5 & -0.5 & 22.8 & 43.9 & 9.4 & -2.0 & 3.3 & -33.7 & -61.8 & -81.1 & -84.1 \\
\hline $\begin{array}{l}\text { Economies in } \\
\text { Transition }\end{array}$ & -2.3 & -6.2 & 2.7 & 3.5 & -23.6 & -47.8 & -29.3 & -26.6 & -34.5 & -57.5 & -95.5 \\
\hline \multicolumn{12}{|l|}{ Memorandum Item: } \\
\hline Heavily Indebted & & & & & & & & & & & \\
\hline $\begin{array}{l}\text { Poor Countries } \\
\text { (HIPCs) }\end{array}$ & 6.4 & 7.0 & 7.5 & 8.6 & 10.0 & 8.8 & 8.7 & 9.8 & 10.0 & 10.6 & 12.3 \\
\hline $\begin{array}{l}\text { Least Developed } \\
\text { Countries }\end{array}$ & 12.9 & 11.3 & 10.4 & 13.3 & 12.6 & 6.4 & 9.7 & 8.3 & 9.1 & 6.1 & 5.2 \\
\hline
\end{tabular}

Note: a: Preliminary estimates

Source: UN (2006) World Economic Situation and Prospects 2006 
Table 25: Net Financial Flows to Developing Countries and Economies in Transition, 1993-2005, Billions of Dollars

\begin{tabular}{|c|c|c|c|c|c|}
\hline \multirow{2}{*}{ Category } & \multicolumn{5}{|c|}{ Average Annual Flow } \\
\hline & 1993-1997 & 1998-2002 & 2003 & 2004 & $2005^{a}$ \\
\hline \multicolumn{6}{|l|}{$\begin{array}{l}\text { Developing Countries } \\
\text { (including Economies in Transition) }\end{array}$} \\
\hline Net Private Capital Flows & 148.4 & 48.2 & 104.6 & 184.0 & 95.4 \\
\hline Net direct investment & 87.5 & 137.8 & 134.4 & 153.7 & 172.1 \\
\hline Net portfolio investment ${ }^{b}$ & 65.4 & -7.2 & -7.3 & 39.6 & -28.2 \\
\hline Other net investment ${ }^{c}$ & -4.5 & -82.3 & -22.4 & -9.4 & -48.5 \\
\hline Net Official Flows & 12.6 & 7.8 & -55.1 & -76.5 & -130.1 \\
\hline Total net flows & 161.0 & 56.1 & 49.5 & 107.5 & -34.7 \\
\hline Change in reserves & -79.9 & -93.9 & -323.2 & -452.1 & -423.7 \\
\hline Net Foreign Financial Inflows & 390.5 & 66.5 & -119.5 & -53.2 & -397.7 \\
\hline \multicolumn{6}{|l|}{ Africa } \\
\hline Net Private Capital Flows & 3.9 & 6.8 & 11.2 & 11.8 & 17.0 \\
\hline Net direct investment ${ }^{b}$ & 3.8 & 12.9 & 15.4 & 14.0 & 19.5 \\
\hline Net portfolio investmentc & 4.0 & 0.2 & -09 & 5.3 & 3.2 \\
\hline Other net investment & -3.9 & -6.3 & -3.3 & -7.4 & -5.7 \\
\hline Net Official Flows & 1.5 & 1.2 & 1.8 & -0.6 & -9.5 \\
\hline Total net flows & 5.4 & 8.0 & 12.9 & 11.2 & 7.5 \\
\hline Change in reserves & -7.2 & -7.3 & -23.1 & -40.2 & -51.1 \\
\hline Net Foreign Financial Inflows & 7.5 & 15.5 & 5.9 & -5.9 & -19.1 \\
\hline \multicolumn{6}{|l|}{ East and South Asia } \\
\hline Net Private Capital Flows & 73.4 & 0.7 & 67.0 & 138.0 & 88.4 \\
\hline Net direct investment ${ }^{\mathrm{b}}$ & 48.1 & 56.8 & 69.5 & 83.3 & 86.5 \\
\hline Net portfolio investmentc & 15.6 & -11.7 & 0.8 & 21.3 & -12.3 \\
\hline Other net investment & 7.6 & -53.7 & -19.7 & 18.2 & -0.4 \\
\hline Net Official Flows & 4.2 & -0.5 & -16.5 & 6.1 & 13.4 \\
\hline Total net flows & 77.6 & 0.2 & 50.5 & 144.0 & 101.8 \\
\hline Change in reserves & -44.2 & -89.7 & -231.5 & -351.0 & -313.4 \\
\hline Net Foreign Financial Inflows & 182.3 & -97.9 & -79.9 & 59.9 & -36 \\
\hline \multicolumn{6}{|l|}{ Western Asia } \\
\hline Net Private Capital Flows & 10.6 & 3.8 & 11.2 & 27.7 & -21.8 \\
\hline Net direct investment ${ }^{b}$ & 4.5 & 4.1 & 11.6 & 11.4 & 17.0 \\
\hline Net portfolio investmentc & -0.6 & -2.9 & 0.4 & 16.1 & -25.8 \\
\hline Other net investment & 6.7 & 2.5 & -0.8 & 0.1 & -13.0 \\
\hline Net Official Flows & 0.0 & -5.4 & -49.8 & -77.7 & -127.6 \\
\hline Total net flows & 10.7 & -1.7 & -38.6 & -50.0 & -149.4 \\
\hline Change in reserves & -5.9 & -1.2 & -29.8 & -36.9 & -29.6 \\
\hline Net Foreign Financial Inflows & 26 & -0.8 & -95.8 & -109.3 & -350.2 \\
\hline \multicolumn{6}{|l|}{ Latin America and the Caribbean } \\
\hline Net Private Capital Flows & 59.4 & 35.4 & 18.5 & 9.9 & 15.3 \\
\hline Net direct investment ${ }^{\mathrm{b}}$ & 30.8 & 62.4 & 36.1 & 46.6 & 46.1 \\
\hline Net portfolio investment ${ }^{c}$ & 40.8 & 1.1 & -9.0 & -10.3 & 1.7 \\
\hline Other net investment & -12.1 & -28.0 & -8.5 & -26.4 & -32.5 \\
\hline Net Official Flows & 2.8 & 12.6 & 7.3 & -5.4 & -9.0 \\
\hline Total net flows & 62.2 & 48.1 & 25.8 & 4.5 & 6.2 \\
\hline Change in reserves & -19.5 & 5.0 & -37.5 & -23.7 & -28.0 \\
\hline Net Foreign Financial Inflows & 164.4 & 136.6 & 32.7 & -4.8 & -0.2 \\
\hline \multicolumn{6}{|l|}{ Economies in Transition } \\
\hline Net Private Capital Flows & 8.5 & 1.0 & 28.4 & 20.9 & 2.2 \\
\hline Net direct investment ${ }^{b}$ & 4.4 & 7.8 & 10.5 & 19.4 & 15.2 \\
\hline Net portfolio investmentc & -0.2 & -3.4 & -3.4 & 4.2 & -16.0 \\
\hline Other net investment & 4.3 & -3.4 & 21.3 & -2.6 & 3.0 \\
\hline Net Official Flows & 7.3 & -0.1 & -4.5 & -3.5 & -4.1 \\
\hline Total net flows & 15.8 & 0.9 & 23.9 & 17.4 & -1.9 \\
\hline Change in reserves & -4.8 & -9.2 & -37.4 & -57.6 & -80.8 \\
\hline Net Foreign Financial Inflows & 35.3 & -6.4 & 38.8 & -1.8 & -82.4 \\
\hline
\end{tabular}

Notes: a: Preliminary estimates

b: including Portfolio debt and equity investment

c: Including short-term and long-term bank lending, and possibly including some official flows to data limitations.

Source: UN (2006) World Economic Situation and Prospects 2006 


\section{Prospects for Augmenting Aid Flows}

A principal reason for net foreign financial flows turning negative is the high burden of debt servicing, noted in Table 16. In view of this Addison et al. (2005) argue that aid should be accompanied by debt relief. Such debt relief can have many favourable effects: it can immediately reduce the burden of debt servicing, and thereby make more public resources available for growth enhancing public investment. This reduces debt overhang, which has often acted as a disincentive for private investment. However, the effects of debt relief are limited if it acts as a substitute for aid. Hence Addison et al. argue for debt relief to accompany increased aid flows.

In addition there have been concerted efforts at arriving at "new" sources of development finance. Two broad categories of additional funding have been discussed in the literature. On the one hand the OECD target of setting aside 0.7 per cent of national income of OECD countries for development aid, a norm which has been observed, primarily in its violation in recent times, needs to be followed. Second several international sources of additional development finance have been advocated. In recent times two broad studies, both conducted by UNU/WIDER, stand out. The first set of studies was published in a special issue of the World Economy, vol. 27, no.2 in 2004 and the second was a study coordinated by Atkinson (2004).

A list of 21 most significant proposals for additional sources of aid financing appears in Box 1 below.

Estimates of the additional funding available from these sources vary considerably especially because, since these measures have not yet been adopted, there is little empirical evidence to suggest their incentive impacts. No one knows, for instance, the impact on financial markets of the imposition of a Currency Transactions Tax (CTT, also known as the Tobin tax). However, especially in some academic circles, there is considerably enthusiasm for select taxes since they may yield a "double dividend". A tax on pollution, for example, reduces pollution as well as generating revenue, a Tobin tax would lower volatility of international capital flows and, therefore, improve monetary management in some countries as well as provide revenues for international aid.

Atkinson (2004) estimated the yield from the CTT to be quite substantial The CTT was estimated to yield $\$ 15-20$ billion a year whereas the carbon tax could raise $\$ 50$ billion. If both these taxes could be imposed the quantum of aid would double, although a fair portion would be spent on administration as well as on providing global public goods.

Both these taxes alone could double current aid flows. The main difficulty behind such measures is that they are administratively hard to implement. Many OECD countries, in particular the US, are averse to ceding any tax authority to an international agency or foreign government. ${ }^{9}$

\footnotetext{
${ }^{9}$ For a discussion of possible administrative arrangements see Jha (2004).
} 


\section{Box 1:Twenty-one recent suggestions for global revenue}

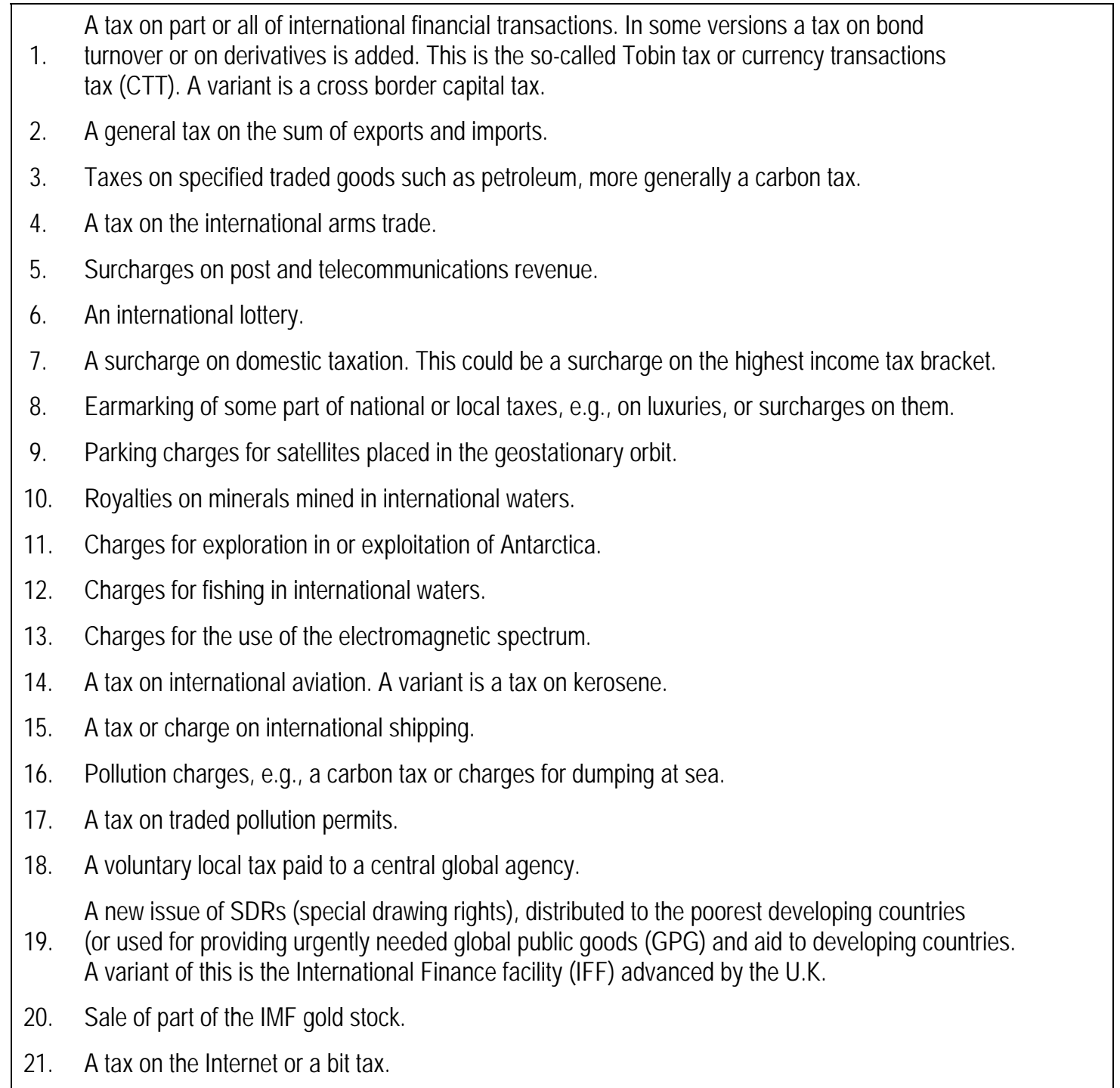

Source: ODI (1996), UK, Jha (2004) and author's compilation

The UK government has proposed an alternative to global taxation in the form of an International Finance Facility (IFF). This facility would work as follows. Developed countries would make long term pledges for annual contributions to an aid fund which would then help leverage additional funding from international capital markets through a process of securitization (IFF bonds). It is estimated that if this facility was begun in 2006 it would yield $\$ 50$ billion during the years $2010-2015$ which would be crucial for the MDG goals. The facility could then be folded by 2020 . However, there are still some administrative problems. Canada and the US are averse to joining this process and the EU has given only lukewarm response, especially because several major European countries are already having difficulties meeting the deficit targets of EU's stability and growth pact and the IFF commitment would put additional strain on finances. 
There is more optimism in the area of private flows and remittances, especially because the US has been receptive to these ideas but reluctant to support measures that would impose international taxation, particularly on its citizens. Private flows and remittances have the advantage that they are already sizable and growing rapidly, however, part of the reason for the enthusiasm may lie in the fact that governments do not have to do much in this area. Currently remittances are running at above $\$ 80$ billion annually much more than current aid flows. Developed county governments can help to increase these flows by reducing banking fees and transactions charges. However, these flows are sent by workers primarily to their families and there is no obvious route through which they could be channelled to meeting the MDG goals. Similar comments apply to the case of charitable donations. Once again the magnitude of flows from such donations is quite high - about 1.5 per cent of income. But most of this is geared towards domestic charities in the developed countries and not to overseas aid. A major exception to this rule, however, had been international donations for the South Asian tsunami of 2004.

A final proposal considered by the UNU-WIDER study is that of a global lottery. This could take the form of a national lottery or a global lottery functioning alongside state and local lotteries that are common in many developed countries. WIDER estimates that this could yield an amount equal to about $\$ 6$ billion a year. A variant of this proposal is to design a global premium bond. Investors would buy these bonds which would then be entered into a draw for an income stream. Those whose bonds are not selected by this draw still retain their claim on the original income stream promised by the bond. In this sense this proposal is more attractive than a lottery. However, similar bonds have been used (in the U.K.) for financing local governments and there is no guarantee that the global bonds will not erode the resource base for such local funding. Thus these bonds are likely to face the opposition of local governments and other governmental bodies in the OECD countries.

Jha (2004) reports quite substantial revenue from aviation taxes. Quoting IPCC (2001) he reports that with a 25 per cent tax revenue yield would in the order of $\$ 12.5$ billion. Similarly large revenues are likely from a tax on kerosene. A ticket levy on international air travel would yield revenue similar to that from a kerosene tax.

A final aviation related revenue-generating measure that has been considered is the international auctioning of emissions permits for polluting airspace. WBGU (2002) argues that if such permits are auctioned globally and annually, the revenue generated will be similar to that from an emissions levy, say a kerosene levy. In 1998 airport use charges in the US alone amounted to US\$ 6.7 billion.

\section{$\underline{\text { Internet (email) Taxation }}$}

The base of this tax is the amount of data being sent through the Internet. The rate of this tax is to be kept very low. Thus a person sending 100 emails per day with a 10kilobyte document would pay a tax of one cent. The revenue potential of this tax is quite substantial: UNDP (1999) estimated that this tax would have yielded US\$ 70 billion in 1996. 


\section{$\underline{\text { Tax on World Trade }}$}

According to WTO the value of world trade in 2000 was $\$ 6.2$ trillion. Assuming an elasticity of 5 per cent in response to a 1 per cent tax, this tax would have yielded US\$ 58.9 billion in revenue in 2000. Given that in recent times world trade growth has generally outpaced world GDP growth, tax yields would be quite buoyant during periods of high economic growth.

\section{$\underline{\text { Tax on Arms Trade }}$}

Another possible source of revenue for international aid is a tax on international arms sales. During 1999-00 the arms trade was worth $\$ 25-30$ billion and a 5 per cent tax could yield $\$ 1.5$ billion, assuming some reduction in arms trade because of the tax.

Other potential sources of revenue discussed by Jha (2004) include fees for the use of the global commons, e.g., parking fees for satellites, a tax on global shipping, the issuing of new SDRs to developing countries and recouping funds held in tax havens,

\section{Improving Aid Quality through better Aid Administration}

Whereas increasing aid flows is desirable for its own sake considerable attention needs to be paid to the administration of aid. We comment on two important aspects of this problem: (i) calibrating aid to suit recipient's absorptive capacity (the so-called aid quality question); and (ii) the volatility of aid.

\section{$\underline{\text { Aid Quality }}$}

Aid quality is defined as the capacity of aid, per dollar, to contribute to development and reduce poverty. Isopil, and Mavrotas (2006) argue that project proliferation has impinged on aid quality. They construct a model in which recipients and donors have objectives other than maximizing the development impact of aid. Such objectives include meeting per diems and the career objectives of aid officials. In such situations, they argue,

On the contrary aid quality is enhanced by measures such as (i) dropping requirements that aid be accepted in kind or spent on donor country goods and services; (ii) harmonization of the procurement, reporting and other requirements of various donors; (iii) alignment of aid flows with recipient's own priorities for spending; (iv) coordinating among donors to ensure non-duplication and (v) non proliferation of projects.

In empirical studies absorptive capacity has been measured by including linear and quadratic aid terms in growth regressions. (Clemens and Radelet 2003, Hadjimichael et al. 1995; Durbarry, Gemmell, and Greenaway 1998; Hansen and Tarp 2000, 2001; Hansen 2001; Lensink and White 2001; Collier and Dollar 2002; Dalgaard, Hansen, and Tarp 2002; Clemens, Radelet, and Bhavnani 2004). Clemens and Radelet (2003) compute that the turning point where aid's marginal productivity on growth starts to fall ranges from 15 per cent to 45 per cent of recipient GDP. A number of explanations are offered for the change in the sign of the impact of aid on growth. Thus, it is argued, that aid may induce laxity in tax effort on the part of the recipients, it can draw away 
the best people from government to the administration of aid and may induce Dutch disease type effects. Moreover, it may encounter bottlenecks in the administrative structure of recipient countries. Poor countries have weak institutions and governance structures which may be stretched thin with large aid programs.

\section{Volatility of aid}

Another factor that impinges on the productivity of aid is its volatility and, in particular, its unpredictability. This has immediate implications for the ability to reach the MDGs. .Reducing such volatility has been a key reason for advancing the International Finance Facility by the U.K. and by Levin and Dollar (2005). Some authors have questioned the ability of impoverished countries such as those in the subSaharan Africa. These are buttressed by empirical evidence from, for example, Lensink and Morrisey (2000) who find that aid volatility negatively impacts upon growth and that this effect is robust across different country groups and different specifications in the growth equation. Moreover, aid appears to have a beneficial effect on economic growth only after volatility is controlled for.

Bulit and Hamann (2003) emphasize the deleterious effects of he volatility of aid using a database covering 72 countries over the period 1975-97. They find that aid is more volatile than tax revenue. Furthermore, aid appears to be the most volatile sources of foreign exchange earnings for many developing countries. Furthermore aid flows are pro-cyclical and hence do not have stabilising properties.

Fielding and Mavrotas (2005) argue that different components of aid display different magnitudes of volatility ${ }^{10}$. In particular they distinguish between sector specific (project) aid and non-sector allocable (program) aid. Their measure of the volatility of aid is a shock to aid that is orthogonal to an information set of lagged macroeconomic variables. Project aid is shown to be positively related to aid volatility. Results for program aid are similar but program aid shows greater volatility than project aid. Moreover more open economies that are richer experience greater volatility in project aid. They also find that recipient countries with better institutions experience lower volatility of aid. These differences are crucial for those recipient countries that are trying to reduce the impact of the volatility of aid through adjustment of public expenditures and, therefore, need to forecast aid volatility for the near term.

In 1999 major funding agencies starting producing Poverty Reduction Strategy Papers (PRSPs). It was hoped that this would lead to better coordination between funding agencies, reduced duplication and, hence, lower volatility of aid. However, Bulír and Hamann (2006) show using a data set covering 76 countries over the period 1975-2003 that aid volatility has shown no tendency to fall. Aid volatility continues to outstrip the volatility of domestically raised resources and aid is highly procyclical. They advocate reduction of macroeconomic instability in the recipient countries to reduce such volatility and advocate the focusing of aid towards this.

Any attempt to substantially increase development aid to developing countries rusn the risk of raising their real exchange rates and, hence, precipitating Dutch disease type

\footnotetext{
${ }^{10}$ Another reason to consider disaggregated versions of aid is that different kinds of aid have different forms of conditionalities attached to them (Killick 2004, and Alesina and Dollar 2000).
} 
conditions. Any enlightened policy should also ensure that the recipient countries do not encounter this condition.

\section{Conclusions}

This paper has examined the prospects for attaining MDG1 in the Asia Pacific region. It began by examining the extant record of economic growth and emphasised the need for higher economic growth in order to accelerate the pace of poverty reduction. The paper has argued that neither the level of economic growth nor its current structure can ensure that MDG1 is attained by 2015 .

The paper argues that domestic savings and investment rates in most large developing countries in the Asia Pacific region are not high enough for growth rates to rise high enough to ensure that MDG1 is attained. Further, the ICOR in most of these countries has been stagnant or rising in many of these countries so that it would be unrealistic to expect sharp enough rises in the productivity of capital to ensure that existing investment rates can ensure that MDG1 is attained by 2015 .

The paper then examines some of the reasons for this lacklustre performance. Tax revenues have been stagnant and public expenditures on education and health have been low whereas many developing countries in the Asia Pacific region bear substantial burdens of debt servicing. Many of these countries also face considerable capital flight, exacerbating already tentative external situations. Furthermore whereas the current outlook for FDI looks promising for some Asian countries, international aid has been stagnant and in, many cases, net financial flows into developing countries has been negative.

The paper then considers avenues for increasing the resource base for these countries. It considers a variety of measures including tax reform and expenditure switching policies. It advances policies to reduce capital flight and argues that international debt reduction should accompany any policy to increase international aid to the developing countries of the Asia Pacific region. It lists a number of additional sources of multilateral aid that could replenish developing country resources but argues that measures to increase the absorptive capacity of developing countries as well as reduction in the volatility of aid must accompany to increase international aid. Further, increases in international aid should ensure that the real exchange rates of the recipient countries should not rise. If the real exchange rates were to rise, some of these countries could be exposed to Dutch disease type of phenomena. 


\section{References}

Addison, T., Mavrotas, G. and M. McGillivrary (2005). "Aid, Debt Relief and New Sources of Finance for Meeting the Millennium Development Goals". Research Paper 2005/9, WIDER, UNU.

African Economic Research Consortium (1998). Tax Reform and Revenue Productivity in Ghana, Nairobi, Kenya: The Regal Press.

Alesina, A. and D. Dollar (2000). 'Who Gives Foreign Aid to Whom and Why?', Journal of Economic Growth, 5: 33-63.

Aryeetey, E. (2004). 'A Development-Focused Allocation of the Special Drawing Rights', in A. B. Atkinson (ed.), New Sources of Development Finance. Oxford:Oxford University Press for UNU-WIDER.

Atkinson, A.B. (ed.) (2004). New Sources for Development Finance. Oxford: Oxford University Press for UNU-WIDER.

Auriol, E. and M. Warlters (2005). "Taxation Base in Developing Countries" Journal of Public Economics, vo. 89, no.3, pp.625-646.

Bird, R., Martinez-Vazquez, J. and B. Torgler (2005). "Societal Institutions and tax Effort in Developing Countries" mimeo.

Bulír, A. and J. Hamann (2006). "Volatility of Development Aid: From the Frying Pan into the Fire?" IMF Working Paper WP/06/65.

Bulír, A. and J. Hamann (2001). 'How Volatile and Unpredictable Are Aid Flows and What are the Policy Implications?', IMF Working Paper, 01/167, International Monetary Fund, Washington DC.

Central Statistical Organization (CSO) (2000). National Sample Survey, 55 ${ }^{\text {th }}$ Round, 1999-00, New Delhi.

Cerra V., Rishi, M. and S. Saxena (2005). "Robbing the Riches: Capital Flight, Institutions, and Instability" Working Paper WP/05/199, Washington, DC: IMF.

Choi, J. and M. Thum (2005). "Corruption and the Shadow Economy" International Economic Review, vol.46, No.3, pp.817-836.

Chu, K., Davoodi, H. and S. Gupta (2004). 'Income Distribution and Tax and Government Social Spending Policies in Developing Countries', in A. Cornia (ed.) Inequality, Growth, and Poverty in an Era of Liberalization and Globalization, New York: Oxford University Press.

Clemens, M., and S. Radelet (2003). 'The Millennium Challenge Account: How Much Is too Much, How Long Is Long Enough?'. Working Paper No. 23. Washington, DC: Center for Global Development.

Clemens, M., S. Radelet, and R. Bhavnani (2004). 'Counting Chickens when They Hatch: The Short Term Effect of Aid on Growth’. Working Paper No. 44. Washington, DC: Center for Global Development.

Collier, P., and D. Dollar (2002). 'Aid Allocation and Poverty Reduction'. EuropeanEconomic Review, 45 (1): 1-26.

Dalgaard, C., H. Hansen, and F. Tarp (2002). 'On the Empirics of Foreign Aid and Growth'. Working Paper No. 02/08. Nottingham: Centre for Research in Economic Development and International Trade, University of Nottingham.

Dreher, A., Kotsogiannis, C. and S. McCorriston (2005). "How do Institutions Affect Corruption and the Shadow Economy?" University of Knostanz and University of Exeter, mimeo.

Dreher, A. and F. Schneider (2006). "Corruption and the Shadow Economy: An Empirical Analysis" Working Paper 2006-01, Centre for Research inEconomics, Management and the Arts, Basel, Switzerland. 
Durbarry, R., N. Gemmell, and D. Greenaway (1998). 'New Evidence on the Impact of Foreign Aid on Economic Growth'. Working Paper No. 98/08. Nottingham: Centre for Research in Economic Development and International Trade, University of Nottingham.

Ebrill, L., Keen, M., Bodin, J. and V. Summers (2001). The Modern VAT, Washington, D.C.: International Monetary Fund.

Emran, M. and J. Stiglitz (2003a). "On Selective Indirect Tax reform in developing countries", Mimeo Columbia University.

Emran, M. and J. Stiglitz (2003b). "Price-Neutral Tax Reform with an Informal Economy" Mimeo Columbia University.

Fielding, D. and G. Mavrotas (2005). “The volatility of aid", Research Paper No.2005/06, UNU WIDER.

Hadjimichael, M. T., D. Ghura, M. Muhleisen, R. Nord, and E. M. Ucer (1995). 'Sub-Saharan Africa: Growth, Savings, and Investment, 1986-93'.

Occasional Paper No.118. Washington, DC: International Monetary Fund.

Hansen, H. (2004). 'The Impact of External Aid and External Debt on Growth and Investment', in T. Addison, H. Hansen, and F. Tarp (eds), Debt Relief for Poor Countries. Basingstoke: Palgrave Macmillian for UNU-WIDER.

Heady, C. (2002). "Tax policy in Developing Countries: What Can be learned from OECD Experience?" Paper presented at the seminar "Taxing Perspectives: A Democratic Approach to Public Finance in Developing Countries" Institute of Development Studies, University of Sussex, UK, October 28-29.

Hermes, N., Lensink, R. and V. Murinde (2002). "Flight Capital and its Reversal for Development Financing" Discussion Paper 2002/99, WIDER, Helsinki.

Isopil, A. and G. Mavrotas (2006). "Aid Allocation and Aid Effectiveness: An Empirical Analysis”, Research Paper No. 2006/07, UNU WIDER.

Jha, R., Mohanty, M., Chatterjee, S. and P. Chitkara (1999). "Tax Efficiency in Selected Indian States" Empirical Economics, vol. 24, no.4, pp.641-654.

Jha, R. (2004a). "Reducing Poverty and Inequality in India: has Liberalization Helped?" in A. Conrnia (ed.) Inequality, Growth and Poverty in an Era of Liberalization and Globalization” New York: Oxford University Press, pp.297-326.

Jha, R. (2004b). "Innovative Sources of Development Finance: Global Cooperation in the Twenty-First Century" The World Economy, vol. 27, no.2, pp.193-214.

Jha, R. (2006). "Macroeconomic Stabilization and Pro-Poor Budgetary Policy in the Globalized Economy" in A. Cornia (ed.) Pro-poor Macroeconomics, Houndmills: UK: Palgrave Macmillan.

Kant, C. (2002). “What is Capital Flight?” World Development, vol. 25, no. 2, pp.341- 348.

Killick, T. (2004). 'Politics, Evidence and the New Aid Agenda', Development Policy Review, 22: $5-29$.

Lensink, R. and O. Morrissey (2000). 'Aid Instability as a Measure of Uncertainty and the Positive Impact of Aid on Growth', Journal of Development Studies, 36: 31-49.

Lensink, R., and H. White (2001). 'Are There Negative Returns to Aid?' Journal of Development Studies, 37 (6): 42-65.

Levin, V. and D. Dollar (2005). 'The Forgotten States: Aid Volumes and Volatility In Difficult Partnership Countries', paper prepared for DAC Learning and Advisory Process on Difficult Partnerships.

Loayza, N., Schmiddt-Hebbel, K. and L. Serven (2000) 'What drives Private Saving Across the World' The Review of Economics and Statistics, vol. 82, no.2, pp. 165-181.

Mavrotas, G. (2004). 'The International Finance Facility Proposal', in A. B. Atkinson (ed.), New Sources of Development Finance. Oxford: Oxford University Press for UNUWIDER. 
Micklewright, J., and A. Wright (2004). 'Private Donations for International Development', in A. B. Atkinson (ed.), New Sources of Development Finance: .Oxford: Oxford University Press for UNU-WIDER.

Mocan, N. (2004). "What determines Corruption? International Evidence from Micro Data" NBER Working Paper 10460.

Munoz, S. and S. Cho (2003). 'Social Impact of a Tax Reform: The Case of Ethiopia', IMF Working Paper WP/03/22.

Nissanke, M. (2004). 'Revenue Potential of the Tobin Tax for Development Finance: A Critical Appraisal', in A. B. Atkinson (ed.), New Sources of Development Finance, Oxford: Oxford University Press for UNU-WIDER.

ODI (Overseas Development Institute) (1996). 'New Sources of Finance for Development'. ODI Briefing Paper 1/96. Available at: www.odi.org.uk/ publications/briefing/odi briefing196.html.

Pasha, H. and T. Palanivel (2004) "Pro-poor Growth and Policies: The Asian Experience" UNDP Working Paper, Colombo.

Piggptt, J. and J. Whalley (2001). "VAT Base Broadening, Self Supply, and the Informal Sector" American Economic Review, 91, pp.1084-1094.

Rodrik, D. (1998). 'Why Do More Open Economies Have Bigger Governments?', Journal of Political Economy, 106(5), 997-1032.

Roodman, D. (2006). "Aid Project Proliferation and Absorptive Capacity” Research Paper No. 2006/04, UNU WIDER.

Sandmo, A. (2004). 'Environmental Taxation and Revenue for Development', in A.B. Atkinson (ed.), New Sources of Development Finance. Oxford: Oxford University Press for UNU-WIDER.

Schneider, B. (2003). "Measuring Capital Flight: Estimates and Interpretations" Working Paper 194, Overseas Development Institute, London.

Schneider,F. (2005). "Shadow Economies of 145 Countries all Over the World: What do we really know? Working Paper 2005-13, Centre for Research in Economics, Management and the Arts, Basel, Switzerland.

Shome, P. (1995). Tax Policy Handbook, International Monetary Fund: Washington DC.

Solimano, A. (2004). 'Remittances by Emigrants: Issues and Evidence', in A.B. Atkinson (ed.), New Sources of Development Finance. Oxford: Oxford University Press for UNUWIDER.

Teera, J. (2002). 'Tax Performance: A Comparative Study', Department of Economics, University of Bath Working Paper No.01/2002.

United Nations (UN) (2006). World Economic Situation and Prospects 2006, Available at http://www.un.org/esa/policy/wess/wesp.html (Accessed 22 March 2006).

United Nations Conference on Trade and Development (UNCTAD) (2005). "Prospects for Foreign Direct Investment and the Strategies of Transnational Corporations 2005-2008" New York and Geneva. Available at http://www.unctad.org/en/docs/iteiit20057_en.pdf (Accessed 22 March 2006).

Warr, P. (2003). "Fiscal Policies and Poverty Incidence: The Case of Thailand" Asian Economic Journal, 17(1), pp.27-44.

Weber Abramo, C. (2005). "How far perceptions go" Transparency Brazil Working Paper, Washington, D.C.: The World Bank.

Winters, A., McCulloch, N. and A.McKay (2002). "Trade Liberalisation and Poverty: The Empirical Evidence" Discussion Paper 88, University of Sussex at Brighton.

World Bank (1991). 'Lessons of Tax Reform', Washington, DC: The World Bank. 
Relationship between Domestic Savings Rate and GDP Growth, 1981-2004

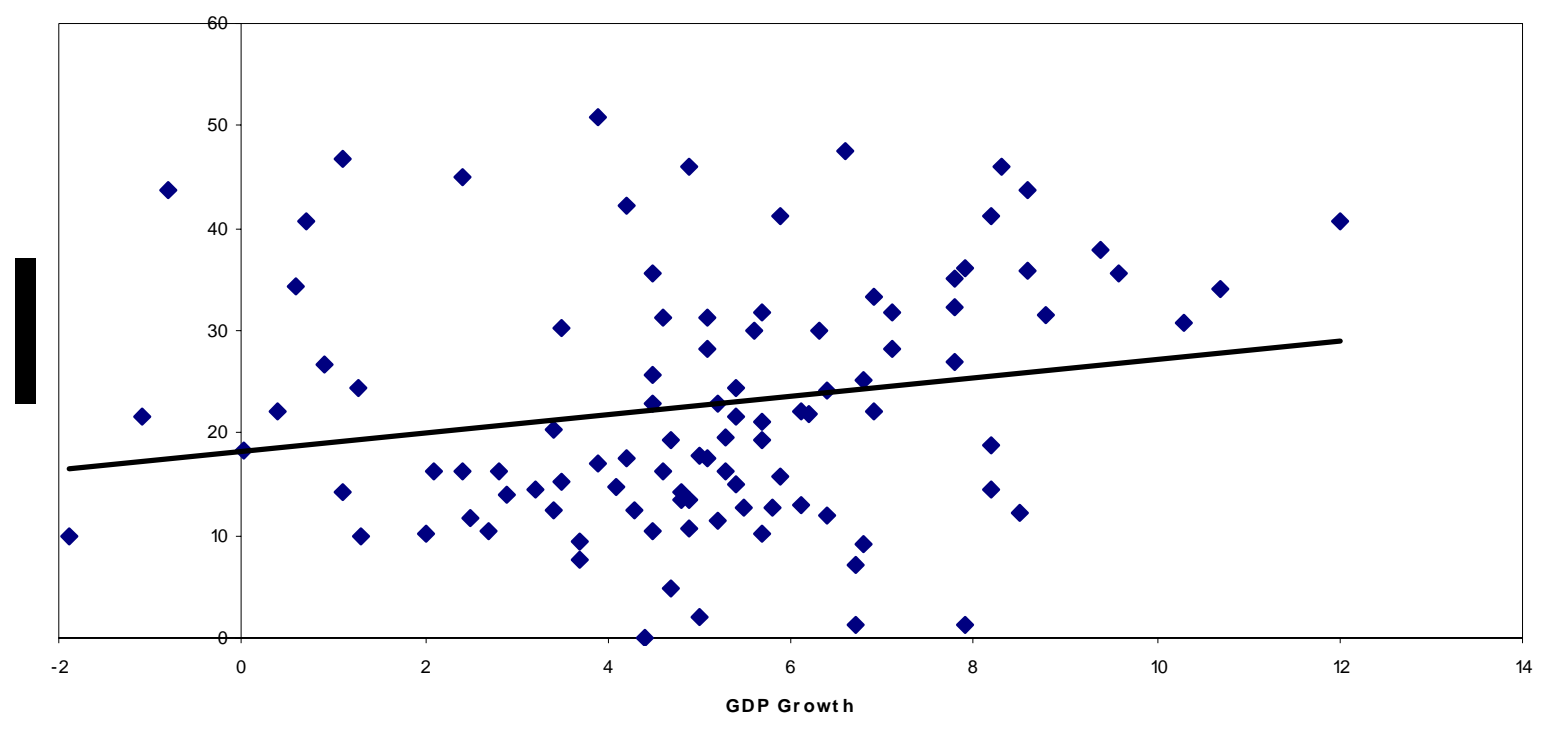

Figure 1

Relationship between Investment Rate (GDFCF) and GDP Growth, 1981-2004

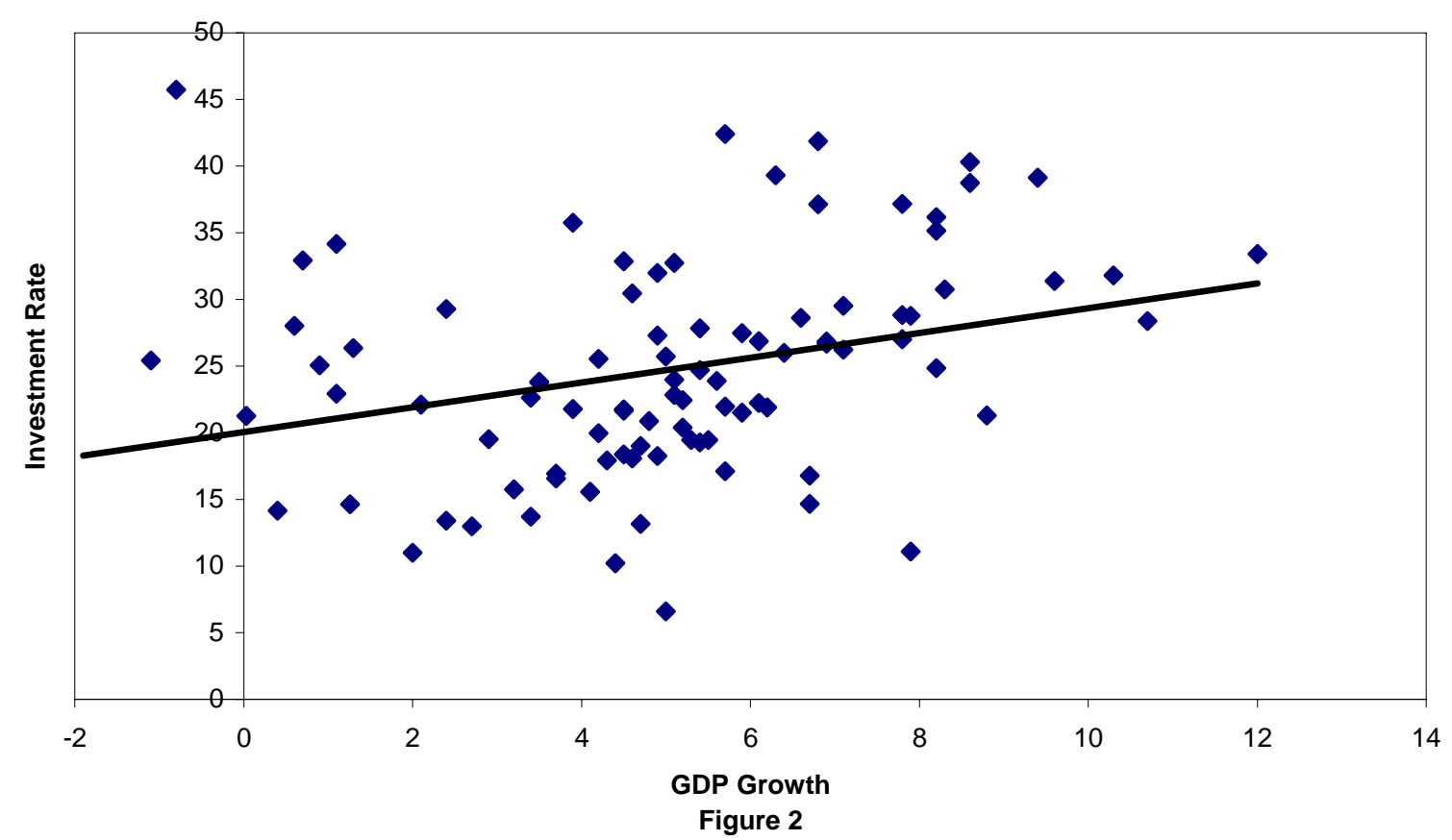


Figure 3

Relationship between Savings Rate and Investment Rate (GDFCF)

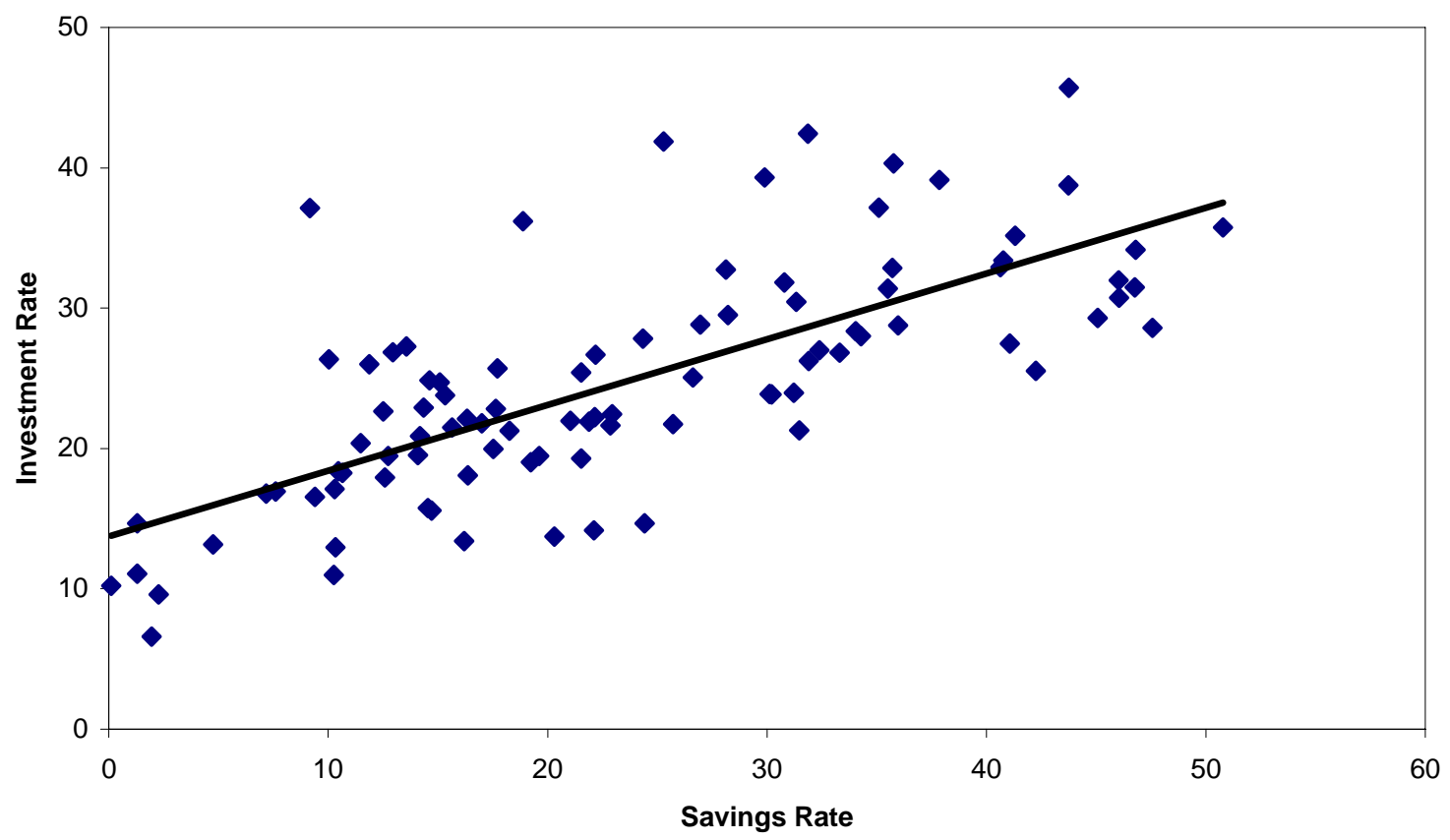

Figure 4

Relationship between Savings Rate and Investment Rate (GCF)

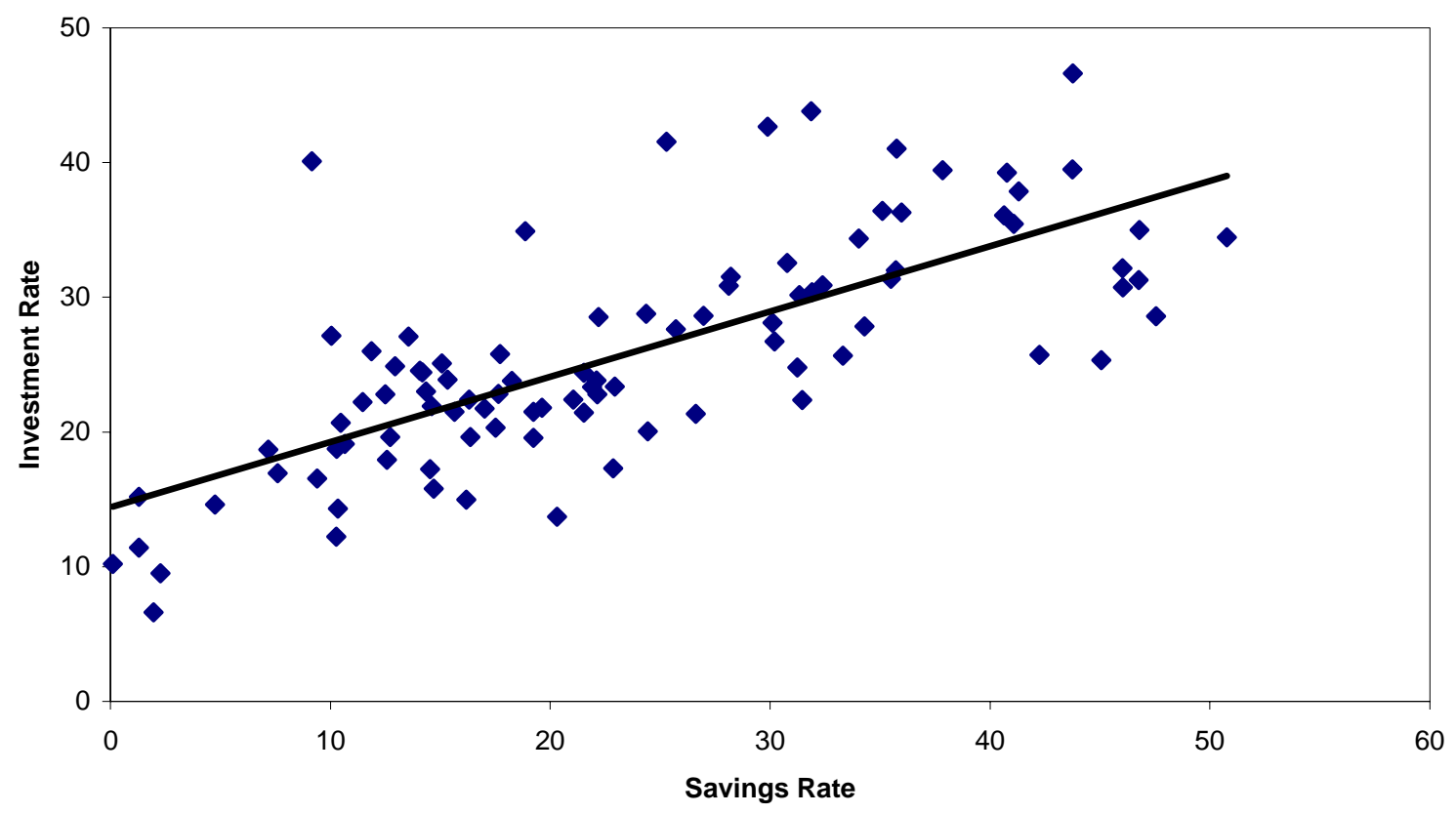


Resource Augmentation for Meeting the MDGs in the Asia-Pacific Region

Figure 5

Relationship between GDP Growth and Investment Rate (GCF)

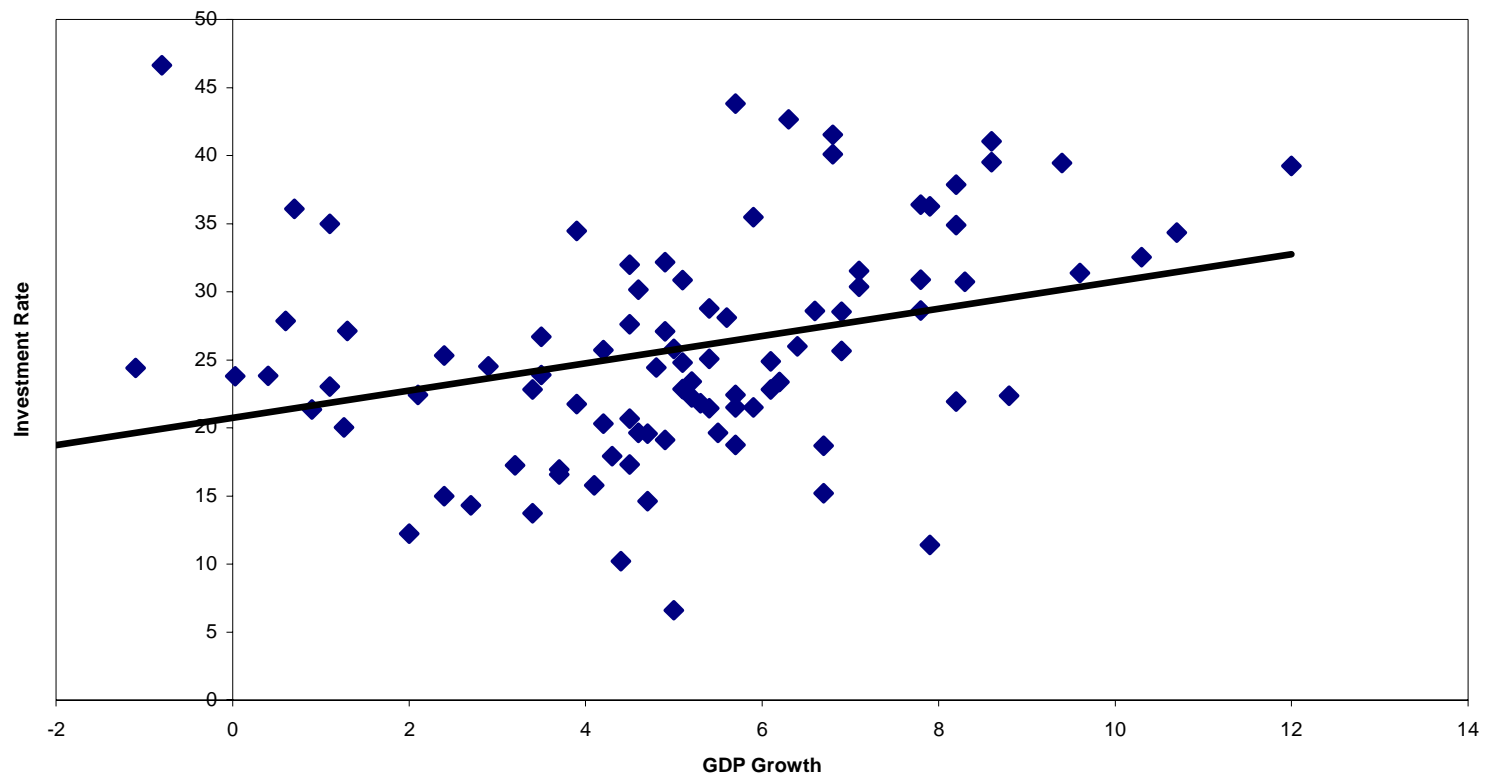


Trends in real GDP growth over the period since 1981 are noted in Table A1.

Table A1: Trends in GDP Growth Rates: 1981-2004 (\% per annum)

\begin{tabular}{|c|c|c|c|c|c|}
\hline Countries/Regions & 1981-1985 & $1986-1990$ & 1991-1995 & $1996-2000$ & $2001-2004$ \\
\hline Bangladesh & 3.7 & 3.7 & 4.3 & 5.9 & 5.1 \\
\hline Bhutan & 6.8 & 8.2 & 5.7 & 6.8 & 6.3 \\
\hline Cambodia & & & 7.9 & 6.7 & 5.5 \\
\hline China & 10.7 & 7.9 & 12 & 8.2 & 8.6 \\
\hline Fiji & 0.03 & 2.4 & 2.7 & 2.0 & 3.4 \\
\hline India & 5.3 & 6.2 & 5.2 & 5.7 & 6.1 \\
\hline Indonesia & 5.6 & 7.1 & 7.8 & 0.9 & 4.5 \\
\hline Iran, Islamic Rep. & 5.4 & 0.4 & 4.5 & 3.5 & 5.9 \\
\hline Korea, Rep. & 7.8 & 9.6 & 7.8 & 4.5 & 4.6 \\
\hline Lao PDR & $5.0^{* \star}$ & 4.4 & 6.4 & 6.1 & 5.7 \\
\hline Malaysia & 5.1 & 6.9 & 9.4 & 4.9 & 4.2 \\
\hline Maldives & & & & 8.3 & 6.6 \\
\hline Mongolia & 6.4 & 2.5 & -8.1 & 2.8 & 5.3 \\
\hline Myanmar & 4.8 & -1.9 & 5.8 & 8.5 & $9.7^{\star}$ \\
\hline Nepal & 4.9 & 4.5 & 5.2 & 4.8 & 2.9 \\
\hline Pakistan & 6.7 & 5.7 & 4.6 & 3.2 & 4.1 \\
\hline Papua New Guinea & 1.3 & 1.1 & 8.8 & 1.26 & 0.5 \\
\hline Philippines & -1.1 & 4.7 & 2.1 & 3.9 & 4.2 \\
\hline Samoa & -0.8 & 0.7 & 1.1 & 3.9 & 2.4 \\
\hline Sri Lanka & 4.9 & 3.4 & 5.4 & 5.0 & 3.5 \\
\hline Thailand & 5.4 & 10.3 & 8.6 & 0.6 & 5.1 \\
\hline Vietnam & $3.8^{\star *}$ & 4.7 & 8.2 & 6.9 & 7.1 \\
\hline East Asia \& Pacific & 7.4 & 7.5 & 10.1 & 6.1 & 7.4 \\
\hline South Asia & 5.3 & 5.8 & 5.0 & 5.3 & 5.7 \\
\hline Latin America \& Caribbean & 0.5 & 1.7 & 3.5 & 3.2 & 1.7 \\
\hline Middle East \& North Africa & 1.1 & 2.3 & 3.4 & 3.4 & 3.6 \\
\hline Sub-Saharan Africa & 0.8 & 2.6 & 1.1 & 3.3 & 3.5 \\
\hline Europe \& Central Asia & & & -4.5 & 2.8 & 4.1 \\
\hline Low income & 3.7 & 4.9 & 3.6 & 5.0 & 5.2 \\
\hline Middle income & 2.1 & 3.0 & 2.9 & 3.9 & 3.5 \\
\hline High income & 2.6 & 3.7 & 2.1 & 3.1 & 1.5 \\
\hline
\end{tabular}

Note: *: Value of 2001, **: Value of 1985

Source: World Bank, WDI CD-ROM, 2003, and ADB key Indicators 2005 
Table A2: Trends in Sectoral GDP Share (\%):1981-2004

\begin{tabular}{|c|c|c|c|c|c|c|c|c|c|c|c|c|c|c|c|}
\hline \multirow[t]{2}{*}{ Countries/Region } & \multicolumn{5}{|c|}{ Agriculture } & \multicolumn{5}{|c|}{ Industry } & \multicolumn{5}{|c|}{ Service } \\
\hline & $\begin{array}{l}1981- \\
1985\end{array}$ & $\begin{array}{c}1986- \\
1990\end{array}$ & $\begin{array}{l}1991- \\
1995\end{array}$ & $\begin{array}{l}1996- \\
2000\end{array}$ & $\begin{array}{l}2001- \\
2004\end{array}$ & $\begin{array}{l}1981- \\
1985\end{array}$ & $\begin{array}{c}1986- \\
1990\end{array}$ & $\begin{array}{l}1991- \\
1995\end{array}$ & $\begin{array}{l}1996- \\
2000\end{array}$ & $\begin{array}{l}2001- \\
2004\end{array}$ & $\begin{array}{c}1981- \\
1985\end{array}$ & $\begin{array}{c}1986- \\
1990\end{array}$ & $\begin{array}{c}1991- \\
1995\end{array}$ & $\begin{array}{c}1996- \\
2000\end{array}$ & $\begin{array}{l}2001- \\
2004\end{array}$ \\
\hline Bangladesh & 31.7 & 31.2 & 27.6 & 25.7 & 22.2 & 21.2 & 21.2 & 23.3 & 25.2 & 26.3 & 46.9 & 47.5 & 49.0 & 49.0 & 51.3 \\
\hline Bhutan & 53.3 & 45.9 & 41.1 & 37.6 & $33.9 *$ & 18.9 & 24.5 & 29.2 & 34.7 & $38.5^{\star}$ & 27.7 & 29.4 & 29.5 & 27.6 & $27.4^{*}$ \\
\hline Cambodia & & & 48.7 & 45.1 & 35.7 & & & 14.1 & 18.6 & 27.7 & & & 37.1 & 36.1 & 36.4 \\
\hline China & 31.6 & 26.3 & 21.8 & 18.4 & 15.1 & 44.4 & 43.3 & 46.0 & 49.6 & 51.0 & 23.8 & 30.3 & 32.6 & 31.9 & 33.7 \\
\hline Fiji & 19.1 & 21.2 & 20.2 & 17.1 & 16.3 & 20.1 & 22.2 & 25.2 & 26.4 & 26.8 & 60.6 & 56.5 & 54.4 & 56.3 & 56.7 \\
\hline India & 35.7 & 31.9 & 30.4 & 27.1 & 22.9 & 22.9 & 27.0 & 26.9 & 26.7 & 26.2 & 38.3 & 41.0 & 42.6 & 46.1 & 50.8 \\
\hline Indonesia & 23.2 & 22.2 & 17.8 & 17.5 & 16.8 & 38.7 & 36.9 & 40.4 & 44.4 & 44.7 & 37.9 & 40.8 & 41.7 & 37.9 & 38.3 \\
\hline Iran, Islamic Rep. & 20.0 & 24.3 & 20.3 & 15.7 & 11.6 & 32.4 & 23.5 & 33.6 & 31.2 & 39.6 & 47.5 & 52.1 & 46.0 & 52.9 & 48.7 \\
\hline Korea, Rep. & & & 5.7 & 4.7 & 3.5 & & & 37.7 & 36.5 & $34.3^{\star}$ & & & 56.5 & 58.6 & 62.0 \\
\hline Lao PDR & & & 58.1 & 53.0 & $50.0^{*}$ & & & 17.9 & 22.0 & $24.7^{*}$ & & & 23.8 & 24.8 & $25.2^{*}$ \\
\hline Malaysia & 20.4 & 18.6 & 13.8 & 11.1 & 9.2 & 38.7 & 39.4 & 40.9 & 45.8 & 48.0 & 40.76 & 41.8 & 45.1 & 43.0 & 42.7 \\
\hline Mongolia & 17.3 & 17.3 & 34.9 & 37.6 & 28.5 & 26.2 & 29.1 & 25.2 & 19.7 & 15.3 & 56.4 & 53.7 & 39.7 & 42.6 & 56.1 \\
\hline Myanmar & 47.8 & 55.4 & 61.0 & 58.8 & & 12.7 & 10.7 & 9.3 & 9.8 & - & 39.4 & 33.8 & 29.5 & 31.3 & \\
\hline Nepal & 58.9 & 51.0 & 43.8 & 40.9 & 40.2 & 13.1 & 16.1 & 20.5 & 22.4 & 22.0 & 27.8 & 32.8 & 35.5 & 36.5 & 37.6 \\
\hline Pakistan & 29.8 & 26.5 & 25.7 & 26.6 & 23.6 & 22.4 & 24.1 & 24.6 & 23.6 & 23.2 & 47.7 & 49.2 & 49.5 & 49.6 & 53.0 \\
\hline Papua New Guinea & 33.9 & 29.6 & 27.1 & 29.0 & $25.7^{\star}$ & 24.8 & 30.8 & 37.2 & 37.8 & $40.6^{\star}$ & 41.2 & 39.5 & 35.6 & 33.0 & $33.5^{*}$ \\
\hline Philippines & 23.9 & 23.1 & 21.6 & 17.8 & 14.6 & 38.0 & 34.7 & 32.8 & 31.7 & 32.2 & 37.9 & 42.1 & 45.5 & 50.4 & 53.0 \\
\hline Sri Lanka & 27.7 & 26.4 & 24.8 & 21.1 & 19.2 & 26.6 & 26.6 & 25.9 & 27.0 & 26.0 & 45.6 & 46.8 & 49.2 & 51.7 & 54.6 \\
\hline Thailand & 18.6 & 15.0 & 10.4 & 9.6 & $9.4^{*}$ & 30.8 & 34.8 & 39.7 & 40.7 & $42.9^{\star}$ & 50.5 & 50.0 & 49.86 & 49.6 & $47.6^{*}$ \\
\hline Vietnam & & 41.1 & 31.7 & 25.8 & $22.7^{\star}$ & & 25.3 & 27.5 & 33.1 & 38.8 & & 33.4 & 40.7 & 41.0 & $38.4^{*}$ \\
\hline East Asia \& Pacific & 29.1 & 25.0 & 20.5 & 17.8 & 14.7 & 41.8 & 40.7 & 43.2 & 46.5 & 48.5 & 29.0 & 34.1 & 36.2 & 35.5 & 36.6 \\
\hline South Asia & 34.7 & 31.3 & 29.6 & 26.9 & 23.0 & 25.0 & 26.1 & 26.2 & 26.2 & 25.8 & 40.1 & 42.5 & 44.0 & 46.8 & 51.0 \\
\hline Latin America \& Caribbean & 10.4 & 9.8 & 8.2 & 7.6 & 6.7 & 39.2 & 38.2 & 33.4 & 29.4 & 25.7 & & & & & \\
\hline Sub-Saharan Africa & 19.6 & 19.8 & 18.6 & 19.4 & 3.7 & 33.8 & 33.6 & 32.6 & 29.6 & 29.7 & 46.4 & 46.6 & 48.6 & 51.0 & 53.0 \\
\hline High income non-OECD & 3.4 & 3.8 & 3.0 & 2.2 & 2.0 & 46.0 & 41.2 & 37.8 & 33.6 & 32.0 & 49.8 & 55.2 & 59.2 & 64 & 66 \\
\hline High income OECD & 3.4 & 3.0 & 2.0 & 2.0 & 2.0 & 35.6 & 33.2 & 30.4 & 28.4 & 27.0 & 60.6 & 64.0 & 67.4 & 69.2 & 71.0 \\
\hline World & 6.2 & 5.4 & 5.0 & 4.2 & 4.0 & 36.6 & 34.2 & 31.6 & 29.8 & 28.0 & & & & & \\
\hline
\end{tabular}

Source: World Bank, WDI CD-ROM, 2003

Note: *: Excluding 2004 